\title{
New insights into the vertical structure of the September 2015 dust storm employing eight ceilometers and auxiliary measurements over Israel
}

\author{
Leenes Uzan ${ }^{1,2}$, Smadar Egert $^{1}$, and Pinhas Alpert ${ }^{1}$ \\ ${ }^{1}$ Department of Geophysics, School of Geosciences, Raymond and Beverly Sackler Faculty of Exact Sciences, \\ Tel Aviv University, Tel Aviv, Israel \\ ${ }^{2}$ The Israeli Meteorological Service, Beit Dagan, Israel
}

Correspondence: Leenes Uzan (leenesu@gmail.com)

Received: 6 July 2017 - Discussion started: 24 August 2017

Revised: 19 January 2018 - Accepted: 24 January 2018 - Published: 6 March 2018

\begin{abstract}
On 7 September 2015, an unprecedented and unexceptional extreme dust storm struck the eastern Mediterranean (EM) basin. Here, we provide an overview of the previous studies and describe the dust plume evolution over a relatively small area, i.e., Israel. This study presents vertical profiles provided by an array of eight ceilometers covering the Israeli shore, inland and mountain regions. We employ multiple tools including spectral radiometers (Aerosol Robotic Network - AERONET), ground particulate matter concentrations, satellite images, global/diffuse/direct solar radiation measurements and radiosonde profiles. The main findings reveal that the dust plume penetrated Israel on 7 September from the northeast in a downward motion to southwest. On 8 September, the lower level of the dust plume reached $200 \mathrm{~m}$ above ground level, generating aerosol optical depth (AOD) above 3 and extreme ground particulate matter concentrations up to $\sim 10000 \mu \mathrm{mm}^{-3}$. A most interesting feature on 8 September was the very high variability in the surface solar radiation in the range of 200$600 \mathrm{~W} \mathrm{~m}^{-2}$ (22 sites) over just a distance of several hundred kilometers in spite of the thick dust layer above. Furthermore, 8 September shows the lowest radiation levels for this event. On the following day, the surface solar radiation increased, thus enabling a late (between 11:00 and 12:00 UTC) sea breeze development mainly in the coastal zone associated with a creation of a narrow dust layer detached from the ground. On 10 September, the AOD values started to drop down to $\sim 1.5$, and the surface concentrations of particulate matter decreased as well as the ceilometers' aerosol indications (signal counts) although Cloud-Aerosol Lidar and In-
\end{abstract}

frared Pathfinder Satellite Observation (CALIPSO) revealed an upper dust layer remained.

\section{Introduction}

An exceptionally extreme dust storm prevailed over the eastern Mediterranean (EM) in September 2015. The Israeli Meteorological Service (IMS) declared the dust storm to be extraordinary as it occurred in early September (710 September), extended over a time span of $100 \mathrm{~h}$ creating extreme ground-level particulate matter (PM) concentrations (e.g., 100 times above the hourly average of $\mathrm{PM}_{10}$ in Jerusalem). On 7 September, prior to the penetration of the dust storm over Israel, IMS reported (http://www.ims.gov.il/ IMS/CLIMATE; in Hebrew) a heat wave over Israel causing harsh weather conditions of 80-90\% relative humidity, $42^{\circ} \mathrm{C}$ in valleys and $38^{\circ} \mathrm{C}$ in mountains. On 8 September, visibility decreased below $3 \mathrm{~km}$ and, consequently, inland aviation was prohibited until 9 September (Fig. 1). Concurrently, severe ground-level PM concentrations resulted with a public warning from outdoor activities issued by the environmental protection ministry. Finally, on 11 September, as visibility increased, the IMS confirmed the dust storm ended, whereas the heat wave was over 2 days later, on 13 September, subsequent to a profound change in weather conditions. The PM concentrations declined to values measured prior to the dust storm (http://www.svivaaqm.net/Default.rtl.aspx; in Hebrew) only on 14 September, though the AERONET mea- 


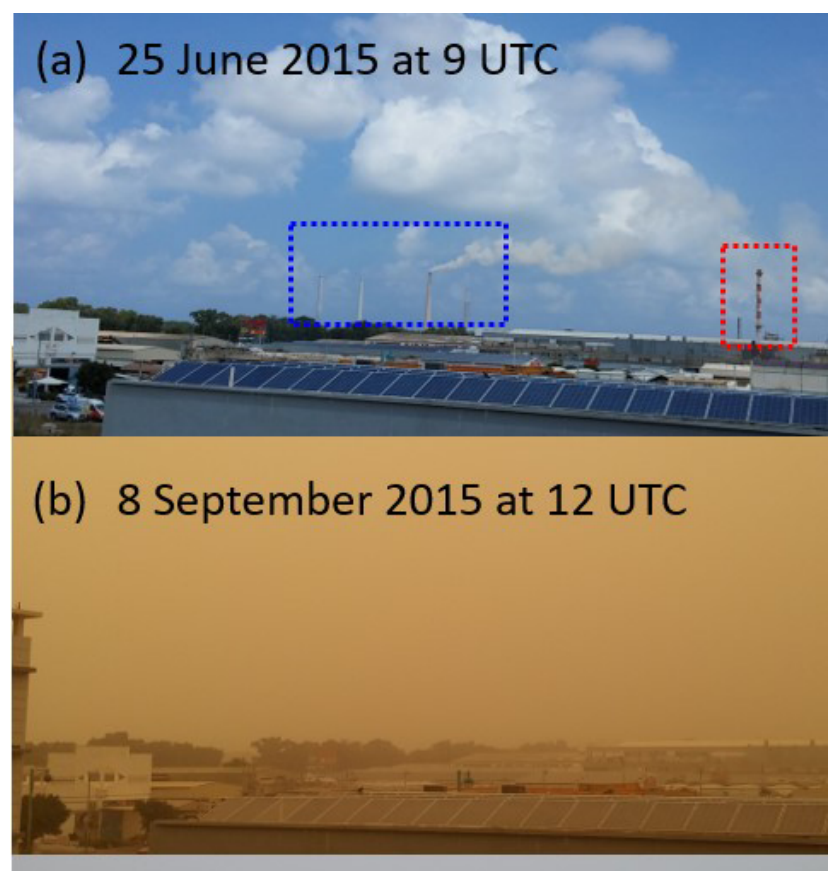

\section{(c) 10 September 2015 at 6 UTC}

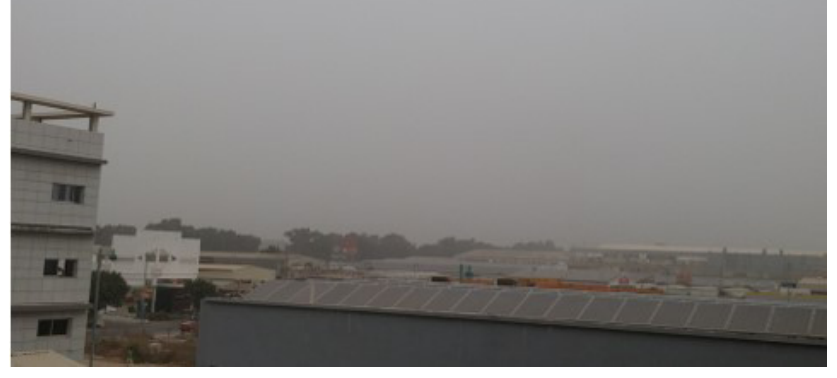

Figure 1. Photographs taken from the central coast of Israel, adjacent to the Hadera ceilometer, $3.5 \mathrm{~km}$ southeast to stacks of a power plant (indicated by a blue rectangle) and $600 \mathrm{~m}$ north to a factory stack (indicated by a red rectangle). The photographs were taken prior to the dust storm, on 25 July 2015 (a), and during the dust storm, on 8 September 2015 (b) and 10 September 2015 (c). Notice that the stacks that are visible on a clear day (a) are invisible during the dust storm $(\mathbf{b}, \mathbf{c})$.

surements (https://aeronet.gsfc.nasa.gov) stationed in central and southern Israel reveal that the aerosol optical depth (AOD) resumed to values prior to the dust storm only on 17 September.

Investigation of the mechanisms leading the severe dust storm was performed by Gasch et al. (2017) using a stateof-the-art icosahedral nonhydrostatic (ICON) dust transport model with the Aerosol and Reactive Trace gases (ART) extension (Rieger et al., 2015). The model concentrated on the EM with one global domain ( $40 \mathrm{~km}$ grid spacing and 90 vertical levels from $20 \mathrm{~m}$ to $75 \mathrm{~km}$ ) and four nested grids (20,10, 5 and $2.5 \mathrm{~km}$ grid spacing and 60 vertical levels from $20 \mathrm{~m}$ to $22.5 \mathrm{~km})$. Simulations were done for three consecutive days

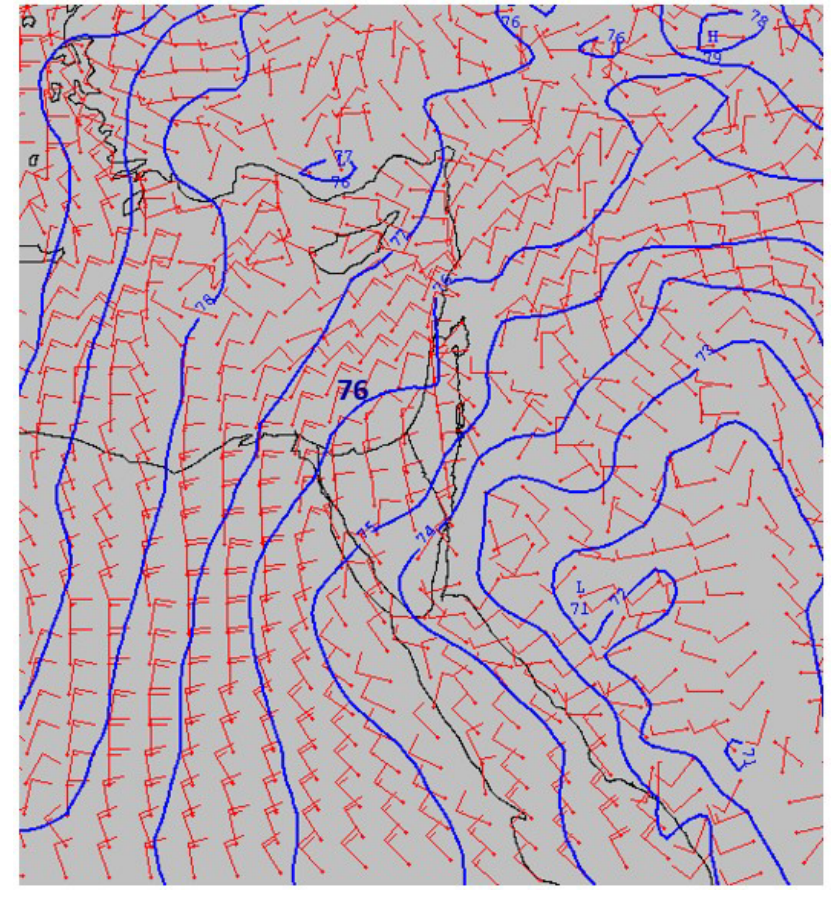

Figure 2. The $925 \mathrm{mb}$ map from 7 September 2015 at 12:00 UTC of $76 \mathrm{dm}$ geopotential height over Israel (blue lines indicate the $1 \mathrm{dm}$ interval) and wind (red arrows; each line indicates $10 \mathrm{KT}$ ). Source: IMS from the British Met Office (UKMO) model.

from 6 to 8 September. Model results delineated an unusual early incidence of an active Red Sea trough (Fig. 2; Alpert et al., 2004) over the historical region of Mesopotamia, followed by mesoscale convective systems over the SyrianIraqi border generating three cold-pool outflows. On the night between 5 and 6 September, a convective system fueled by an inflow along the eastern side of the Red Sea trough moved northeast over the Turkish-Syrian border region. The convective system intensified overnight and generated a first weak cold-pool outflow on 6 September. After sunrise, an increase of surface wind speeds caused dust to pick up over Syria. The atmospheric instability over the Syrian-Iraqi border created a second convective cold-pool outflow from the Zagros mountain range west into Syria. The gust from the second cold-pool outflow ignited a third cold-pool outflow at 20:00 UTC which moved southerly along the eastern flank of the Red Sea trough. On 7 September at 10:00 UTC, rainfall and an increase of surface wind speeds northwest of Syria strengthened the third cold-pool outflow, leading to transportation of enormous dust emissions (up to $5 \mathrm{~km}$ ) southwest. By nightfall of 7 September, the aged second coldpool outflow merged with the third cold-pool outflow over Jordan and southwestern Syria. After midnight, between 7 and 8 September, the dust was transported over Israel. Model simulations were compared to in situ measurements and satellite images: visible electromagnetic spectrum from 
Moderate Resolution Imaging Spectroradiometer (MODIS; https://modis.gsfc.nasa.gov/) aboard the Aqua satellite; AOD from the Terra satellite; red-green-blue (RGB) dust product from the Spinning Enhanced Visible and Infrared Imager (SEVIRI) on the Meteosat Second Generation (MSG) satellite; total attenuated backscatter from Cloud-Aerosol Lidar and Infrared Pathfinder Satellite Observation (CALIPSO; https://www-calipso.larc.nasa.gov/). Investigation over Israel employed measurements from ground-level meteorological stations (three sites) and PM measurements (three sites). Results revealed the model lacked sufficient development of a super critical flow, which in effect produced the excessive surface wind speeds. Eventually, this misled the forecast of the dust advection southwest into Israel.

The fact that forecast models did not succeed in predicting this outstanding dust event motivated Mamouri et al. (2016) to study its origin and development. Their research presented dust load observations in the Cyprus region. Luckily, at the time of the dust storm, a European Aerosol Research Lidar Network (EARLINET; https://www.earlinet.org/) Raman lidar stationed in Limassol provided vertical dust profiles and valuable optical dust properties of backscatter, extinction, lidar ratio and linear depolarization ratio. They analyzed the aerosol optical thickness (AOT) and Ångström exponent derived from the MODIS Aqua satellite. MODIS Aqua AOT measurements were compared to the Limassol lidar observations, AOD measurements from two AERONET sites (Cyprus and Israel) and ground-level $\mathrm{PM}_{10}$ concentration from four Cyprus sites. On 7 September, EARLINET lidar observations measured two dust layers (extending up to $1.7 \mathrm{~km}$ a.s.l. and between 1.7 and $3.5 \mathrm{~km}$ a.s.l.). The dust particle extinction coefficient measured in Limassol had reached $1000 \mathrm{Mm}^{-1}$, followed by high $\mathrm{PM}_{10}$ concentration of $2000 \mu \mathrm{m} \mathrm{m}^{-3}$. Extreme values over Limassol were reported on 8 September as MODIS Aqua AOT observations exceeded 5 (assuming overestimation up to 1.5 ) and hourly $\mathrm{PM}_{10}$ concentration of about $8000 \mu \mathrm{m} \mathrm{m}^{-3}$ (with uncertainties on the order of $50 \%$ ). Unfortunately, on 8 September, the lidar was intentionally shut down to avoid potential damage to the instrument. Lidar observations indicated another dense dust outbreak (1-3 km a.s.l.) reaching Limassol on 10 September, also visible by MODIS Aqua AOT. The researchers concluded the scale of the dust storm features was too small for global and regional dust transport models. They presumed that the initiation of the dust plume was due to an intense dust storm (haboob) in northeastern Syria and northern Iraq, leading to vigorous downbursts which consequently pushed huge amounts of dust and sand to the atmosphere. The lidar observations indicated a double layer structure of the dust, 1.5 and $4 \mathrm{~km}$ a.s.l., pointing to multiple dust sources.

Solomos et al. (2017) continued the investigation of the formation and mechanism of the dust storm over Cyprus by a high regional atmospheric model of the integrated community limited area modeling system (RAMS-ICLAMS). The model simulations focused on the generation of the dust storm on 6 and 7 September. Model results were fine tuned by observations from EARLINET lidar stationed in Limassol, radiosonde data from five sites (Cyprus, Israel and Jordan, and two from Turkey) and satellite imagery from MSGSEVIRI and CALIPSO's Cloud-Aerosol Lidar with Orthogonal Polarization (CALIOP). The model was set to three grid space domains: an external grid of $12 \times 12 \mathrm{~km}$ (over the $\mathrm{EM}$ ), an inner set at $4 \times 4 \mathrm{~km}$ (over northern $\mathrm{EM}$ ) and $2 \times 2 \mathrm{~km}$ grid for cloud resolving (over northeastern Syria). The vertical structure consisted of 50 terrain-following levels up to $18 \mathrm{~km}$. The researchers estimated a strong thermal low over Syria was followed by convection activity over the Iraq-Iran-Syria-Turkey borderline. Combined with land-use changes (aftermath of the war in Syria), these conditions manufactured the extreme dust storm. The model succeeded in describing the westward dust flow of a haboob containing the dust previously elevated over Syria also observed by MSG-SEVIRI and EARLINET lidar. However, there were some inaccuracies in the quantification of dust mass profiles. The researchers attributed the model discrepancies to the limited ability of the model to properly resolve dust and atmospheric properties (e.g., change of land use and intense downward mixing).

$\mathrm{Pu}$ and Ginoux (2016) examined the connection between the natural climate variability (the Pacific Decadal Oscillation) and the dust optical depth (DOD) in Syria between the years 2003 and 2015. DODs were derived by the deep blue algorithm (Hsu et al., 2013) aerosol product from MODIS Terra and MODIS Aqua satellites (10 km resolution). AODs were estimated by the European Centre for Medium-Range Weather Forecasts (ECMWF) reanalysis model (horizontal resolution of $80 \mathrm{~km}$ and 37 vertical levels) and produced by the Geophysical Fluid Dynamics Laboratory (GFDL) atmospheric model (AM3) (Donner et al., 2011). In addition, the AM3 model produced mass distribution and optical properties of aerosols, their chemical production, transport and dry or wet deposition. Comparison of the model AODs, AERONET AOD measurements and DODs from satellite observations revealed the model underestimated the AODs particularly in the EM. The authors assumed that the soil moisture parameters in the model were not set properly resulting in the AOD dissimilarities.

The impact of the conflict in Syria on the aridity of the region, and therefore a possible direct impact on the generation of the September dust storm was examined by Parolari et al. (2016). The researchers conducted simulations using the Advanced Research Weather Research and Forecasting (WRF-ARW) model from 30 August 2015 to 10 September 2015 over the EM. The model consisted of two nested domains (9 and $3 \mathrm{~km}$ grid spacing and 35 vertical levels). Daily and monthly AOD data from MODIS were computed by the deep blue algorithm over land. The monthly average of September 2015 vegetation status in the region was estimated by MODIS normalized difference vegetation index (NDVI). Historical data were divided into two periods: none-drought 
Table 1. The publications on the September 2015 dust event.

\begin{tabular}{|c|c|c|c|}
\hline Main outcome & Main tool & Title & Publications \\
\hline $\begin{array}{l}\text { Model underestimation in the EM } \\
\text { due to inaccurate soil moisture }\end{array}$ & $\begin{array}{l}\text { MODIS Terra and MODIS } \\
\text { Aqua dust optical depth } \\
\text { (DOD) AOD, GFDL-AM3 } \\
\text { model }\end{array}$ & $\begin{array}{l}\text { The impact of the Pacific Decadal } \\
\text { Oscillation on springtime dust ac- } \\
\text { tivity in Syria }\end{array}$ & Pu and Ginoux (2016) \\
\hline $\begin{array}{l}\text { Unusual low-level westerly wind } \\
\text { spread to the EM, to reversely } \\
\text { transport the previously eastward } \\
\text { particles back to the EM }\end{array}$ & WRF model & $\begin{array}{l}\text { Climate, not conflict, explains ex- } \\
\text { treme Middle East dust storm }\end{array}$ & Parolari et al. (2016) \\
\hline $\begin{array}{l}\text { Dust plumes from Syria entered } \\
\text { the EM in a double layer struc- } \\
\text { ture, pointing to multiple dust } \\
\text { sources }\end{array}$ & $\begin{array}{l}\text { MODIS, EARLINET pro- } \\
\text { files and } \mathrm{PM}_{10}\end{array}$ & $\begin{array}{l}\text { Extreme dust storm over the east- } \\
\text { ern Mediterranean in Septem- } \\
\text { ber 2015: satellite, lidar and sur- } \\
\text { face observations in the Cyprus } \\
\text { region }\end{array}$ & Mamouri et al. (2016) \\
\hline $\begin{array}{l}\text { Low model ability to simulate } \\
\text { the event due to inaccuracies in } \\
\text { model physical processes }\end{array}$ & $\begin{array}{l}\text { RAMS model, EARLINET } \\
\text { lidar, MSG and CALIPSO }\end{array}$ & $\begin{array}{l}\text { Remote sensing and modeling } \\
\text { analysis of the extreme dust } \\
\text { storm hitting the Middle East and } \\
\text { EM in September } 2015\end{array}$ & Solomos et al. (2017) \\
\hline $\begin{array}{l}\text { Two dust storms simultaneously, } \\
\text { from northern Syria and the } \\
\text { Sinai desert, created by two low- } \\
\text { pressure systems }\end{array}$ & $\begin{array}{l}\text { Satellite MSG-SEVIRI, } \\
\text { MeteoInfo model }\end{array}$ & $\begin{array}{l}\text { Investigation of the } 6-9 \text { Septem- } \\
\text { ber } 2015 \text { dust storm over the Mid- } \\
\text { dle East }\end{array}$ & Jasim (2016) \\
\hline $\begin{array}{l}\text { An unusual early active Red } \\
\text { Sea trough with mesoscale con- } \\
\text { vective systems generating cold- } \\
\text { pool outflows producing the dust } \\
\text { storm; model lacked develop- } \\
\text { ment of a supercritical flow to } \\
\text { produce excessive wind speeds }\end{array}$ & ICON-ART model & $\begin{array}{l}\text { An analysis of the September } \\
2015 \text { severe dust event in the } \\
\text { eastern Mediterranean }\end{array}$ & Gasch et al. (2017) \\
\hline
\end{tabular}

(2001-2006) and drought (2007-2010). Wind shear stress was calculated to estimate wind erosion. The main findings reveal that the enhanced dust uplift and transportation of the September 2015 dust storm were due to meteorological conditions rather than the land-use changes attributed to the civil conflict in Syria. WRF simulations revealed northwesterly winds west of the low-pressure zone in the Syrian-Iraqi border were associated with dust storms in the Middle East (Rao et al., 2003). The source of elevated dust concentrations over the EM coast on 7 and 8 September were attributed to the cyclone front movement. On 6 September, low-level winds $(700 \mathrm{hPa})$ were opposite the northwesterly high-level winds $(300 \mathrm{hPa})$, consequently generating enhanced surface shear stress and transported resuspended PM westward. Furthermore, based on the past 20 years, the Israeli summer of 2015 was unusually dry and hot, and therefore enabled easier updraft of dust soil increasing the probability of dust emissions.

Jasim (2016) compared the dust plume aerosol content provided by MSG-SEVIRI observations to the generation of the dust storm produced by the open-source MeteoInfo model (Wang, 2014). The MeteoInfo model was based on meteorological variables from ECMWF. The model revealed a formation of two simultaneous dust storms, from northern Syria and the Egyptian Sinai desert, as a result of updrafts created by low-pressure systems.

The aforementioned studies (summarized in Table 1) focused on the generation of the dust storm in the Syrian region based on transport models, satellite imagery, remote and in situ measurements. In our study, we focus on the evolution of the dust plume over Israel in the lower atmosphere based on an array of eight ceilometers and auxiliary instruments described in Sect. 2. The list of instruments includes ceilometers, PM measurements, AERONET, radiosonde, solar radiation and satellite imagery. Section 3 presents the delineation of the dust plume spatial and temporal scheme from 7 to 10 September 2015. We discuss and compare the results between the different measurements. Conclusions and main findings of the dust plume progress in the lower atmosphere are given in Sect. 4. 


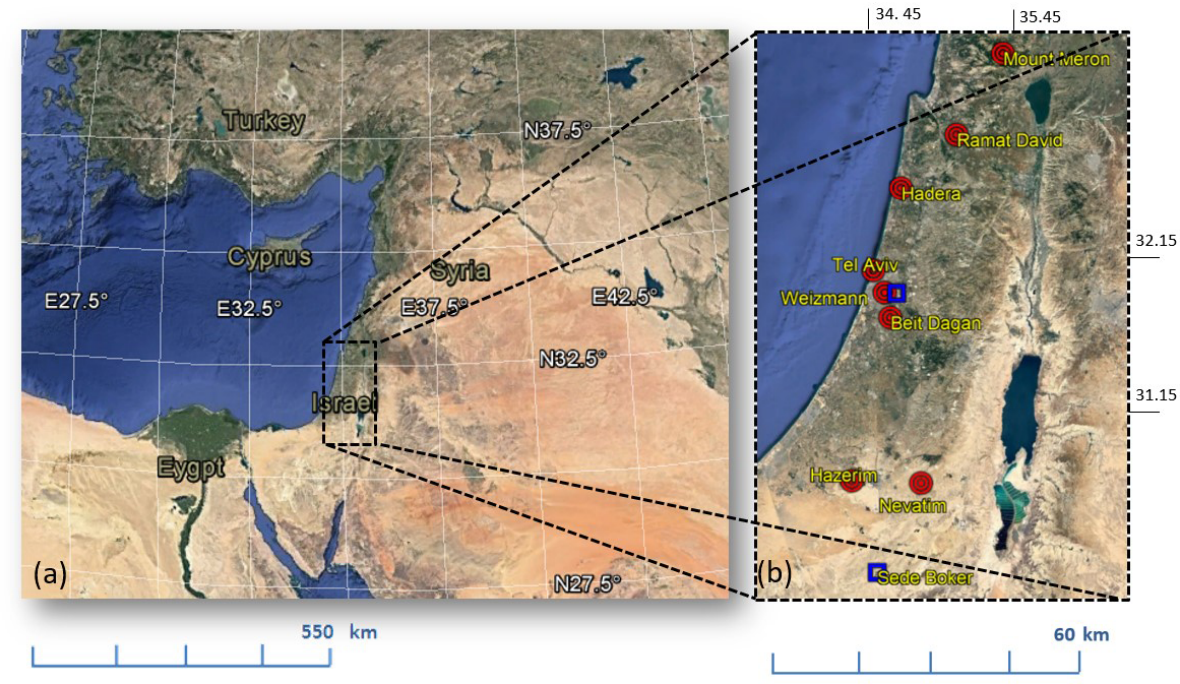

Figure 3. Google Earth map of the large domain (a) and Israel (b) with indications of eight ceilometer sites (red circle; details in Table 2) and two AERONET sites (blue square).

Table 2. Ceilometers' locations.

\begin{tabular}{llrrr}
\hline Location & Site & Long/Lat & $\begin{array}{r}\text { Distance from } \\
\text { shoreline }(\mathrm{km})\end{array}$ & $\begin{array}{r}\text { Height } \\
(\mathrm{m} \text { a.g.1. })\end{array}$ \\
\hline Mount Meron & Northern & $33.0 / 35.4$ & 31 & 1150 \\
Ramat David & Northern & $32.7 / 35.2$ & 24 & 50 \\
Hadera & Onshore & $32.5 / 34.9$ & 3.5 & 10 \\
Tel Aviv & Onshore & $32.1 / 34.8$ & 0.05 & 5 \\
Beit Dagan & Inland & $32.0 / 34.8$ & 7.5 & 33 \\
Weizmann $^{\mathrm{a}}$ & Inland & $31.9 / 34.8$ & 11.5 & 60 \\
Nevatim & Southern & $31.2 / 34.9$ & 44 & 400 \\
Hatzerim & Southern & $31.2 / 34.7$ & 70 & 200 \\
\hline
\end{tabular}

a The ceilometer at the Weizmann Institute is a CL51.

\section{Instruments}

\subsection{Ceilometers}

Lidars are widely used for aerosol studies (Ansmann et al., 2011; Papayannis et al., 2008) including desert dust characteristics and transport process (Mona et al., 2012). Ceilometers, initially intended for cloud-level height detection, are automatic low-cost lidars widespread in airports and weather stations worldwide. As single-wavelength lidars, ceilometers cannot produce the information aerosol properties such as size distribution, scattering and absorption coefficients. Nevertheless, with improvement of hardware and firmware over the years, ceilometers have become a valuable tool in the study of the atmospheric boundary layer and the vertical distribution of aerosols layers (Haeffelin and Angelini, 2012; Ansmann et al., 2003). Furthermore, in 2013, ceilometers were assimilated in the European Meteorological Services Network (EUMETNET) profiling program across Europe (http://eumetnet.eu/activities/observations-programme/
Table 3. Ceilometers' configurations.

\begin{tabular}{lcrrr}
\hline Location & Type & $\begin{array}{r}\text { Time } \\
\text { resolution (s) }\end{array}$ & $\begin{array}{r}\text { Height } \\
\text { resolution (m) }\end{array}$ & $\begin{array}{r}\text { Height range }^{\mathrm{a}} \\
(\mathrm{km})\end{array}$ \\
\hline Mount Meron & CL31 & 16 & 10 & 7.7 \\
Ramat David & CL31 & 16 & 10 & 7.7 \\
Hadera & CL31 & 16 & 10 & 7.7 \\
Tel Aviv & CL31 & 16 & 10 & 7.7 \\
Beit Dagan & CL31 & 15 & 10 & 7.7 \\
Weizmann & CL51 & 16 & 10 & 15.4 \\
Nevatim & CL31 & 16 & 10 & 7.7 \\
Hatzerim & CL31 & 16 & 10 & 7.7 \\
\hline a Height range depends on sky conditions and is limited as AOD increases. In all ceilometers except \\
the one at the Beit Dagan site, data acquisition was limited to 4.5 km based on the BLview firmware.
\end{tabular}

current-activities/e-profile/alc-network/). The main research tool in this study is the Vaisala ceilometer type CL31, which is commonly deployed worldwide.

CL31 is a pulsed elastic micro-lidar, employing an indium-gallium-arsenide (InGaAs) laser diode transmitter of near-infrared wavelength $\left(910 \pm 10 \mathrm{~nm}\right.$ at $\left.25^{\circ} \mathrm{C}\right)$. In order to compensate the low pulse energy of the laser (hence defined "eye-safe") and to provide sufficient signal-to-noise ratio, the pulse repetition rate is of $10 \mathrm{kHz}$ (Vaisala ceilometer CL31 user guide: http://www.vaisala.com). The backscatter signals are collected by an avalanche photodiode (APD) receiver and designed into range-corrected signal profiles within a reporting interval of $2-120 \mathrm{~s}$ (determined by the user) given in relative units (signal counts). The ceilometer profiles are automatically corrected by a cosmetic shift of the backscatter signal (to better visualize the clouds' base), an obstruction correction (when the ceilometer's window is blocked by a local obstacle) and an overlap correction (to the height where the receiver field of view reaches complete overlap with the emitted laser beam). 
Table 4. Ceilometer technical information.

\begin{tabular}{llllll}
\hline Location & Type & Engine board & Receiver & Transmitter & Firmware \\
\hline Beit Dagan & CL31 & CLE311 & CLR311 & CLT311 & 1.72 \\
Weizmann & CL51 & CLE321 & CLRE321 & CLT521 & 1.03 \\
\hline
\end{tabular}

Vaisala provides a scaling factor transferring signal counts to attenuated backscatter units by a multiplication factor of $10^{-8}$. The scaling factor was obtained using a calibration procedure operated on a several instruments and crosschecked by a signal integral from water clouds. The uncertainty of calibrated attenuated backscatter profile (with a $100 \%$ clean window condition) was of $\pm 10 \%$. The uncertainty for the estimated attenuated backscatter was of $\pm 20 \%$ (Christoph Münkel, private communication, 2017). However, Kotthaus et al. (2016) emphasize that this internal calibration applied to convert the signal count output to attenuated backscatter units does not always fully represent the actual lidar constant; therefore, it is not accurate enough for meteorological research. Hence, in this study, we defined the ceilometer profiles as range-corrected signal profiles in arbitrary units.

Kotthaus et al. (2016) examined the Vaisala CL31 ceilometer by comparing attenuated backscatter profiles from five units with different specification of sensor hardware, firmware and operation settings (noise, height and time reporting interval). Research findings show the instrument characteristics that affect the quality and availability of the attenuated backscatter profiles are as follows. At high altitudes, a discontinuity in the attenuated backscatter profile is evident at two height points: $\sim 4949$ and $7000 \mathrm{~m}$. Background signals (instrument related) and cosmetic shift (firmware dependent) tend to be either negative or positive up to $6000 \mathrm{~m}$ and then switch signs above $\sim 6000 \mathrm{~m}$. Below $70 \mathrm{~m}$, an overlap correction is applied internally by the ceilometer sensor as well as an obstruction correction (below $50 \mathrm{~m}$ ). Between 50 and $80 \mathrm{~m}$, hardware-related perturbation causes a slight offset in the attenuated backscatter values. The authors advise that the user-defined reporting interval should be no shorter than $30 \mathrm{~s}$ to avoid consecutive profiles' partial overlap. Background noise reduction can be achieved by a procedure based on a long averaging period during nighttime during a clear atmosphere. A range-corrected attenuated backscatter can be derived by the attenuated backscatter profiles during an existence of a stratocumulus cloud.

Wiegner et al. (2014) studied different retrieval methods to derive the aerosol backscatter coefficient from the ceilometers' attenuated backscatter profiles based on a comparison to auxiliary collocated instruments such as a Sun photometer or a multiwavelength lidar. They focused on calibration methods, the rage detection limitations by the overlap function and the sensitivity of the attenuated backscatter signal to relative humidity. Although the ceilometer wavelength range (given as $905 \pm 3 \mathrm{~nm}$ ) is influenced by water vapor absorption, in the case of aerosol layer detection, water vapor distribution has a small effect on the signal change, indicating the mixed layer height (MLH) or an elevated mixed layer, as the aerosol backscatter itself remains unchanged (Wiegner and Gasteiger, 2015). Consequently, except for the case of a dry layer in a humid MLH, water vapor is unlikely to lead to misinterpretation of the aerosol stratification. Fortunately, most algorithms are based on a significant signal slope to define the aerosol layers and therefore can be determined from uncalibrated ceilometer attenuated backscatter profiles.

In this research, the ceilometer array is comprised of eight units in different sites (Fig. 3 and Tables 2-3), six of which are owned by a governmental office. The ceilometers are CL31 type, apart from ceilometer CL51 stationed in the Weizmann Institute which has a higher backscatter profile range (up to $15.4 \mathrm{~km}$; Münkel et al., 2011). Unfortunately, calibration procedures were not held and maintenance (cleaning of the ceilometer window) was done regularly only for the Beit Dagan ceilometer. Apart from the Beit Dagan and Weizmann ceilometers, we could not retrieve the technical information of firmware and hardware type (Table 4). However, we have received confirmation (personal communication) that the combination of hardware and firmware had been done following Kotthaus et al. (2016). The Beit Dagan ceilometer signal count was found to be weaker (up to 800 signal count compared to 10000 in the other CL31 ceilometers) due to different hardware definitions. Therefore, in order to present the Beit Dagan range-corrected signal profiles aligned with the profiles of the other ceilometers (given in Fig. 17), the Beit Dagan range-corrected signal values were multiplied by $12.5(10000 / 800)$. We address the aforementioned limitations of the ceilometers' measurements in the first range gates as we refer to the ceilometer signal count from $100 \mathrm{~m}$ a.g.l.. Due to the extreme AOD values of the September dust storm, high extinction of the ceilometer signal limited the height of profile analyzed down to $1000 \mathrm{~m}$ a.g.l..

\subsection{Radiosonde}

Radiosonde (RS) type Vaisala RS41-SG is launched by the IMS twice a day at 00:00 UTC and 12:00 UTC from the Beit Dagan site adjacent to the Beit Dagan ceilometer. The radiosonde produces profiles of humidity, temperature, pressure, wind speed and wind direction. The output files were downloaded from the University of Wyoming site (http://weather.uwyo.edu/upperair/sounding.html; sta- 
Table 5. Hourly maximum concentration of $\mathrm{PM}_{2.5}$, collected from 21 monitoring sites, between 7 and 10 September 2015 . The values are ranked from low (dark green) to high (dark red) values.

\begin{tabular}{clcccccc}
\hline & & & \multicolumn{4}{c}{ PM $_{2.5}\left(\mu \mathrm{g} \mathrm{m}^{-3}\right)$} \\
\cline { 4 - 7 } No. & Site & Height $(\mathrm{m}$ a.s.1.) & Region & 7 -Sep-15 & 8 -Sep-15 & 9 -Sep-15 & 10 -Sep-15 \\
\hline 1 & Kfar Masaryk & 8 & North & 52 & 378 & 389 & 378 \\
2 & Ahuza & 280 & North & 36 & 743 & 650 & 419 \\
3 & Newe Shaanan & 240 & North & 43 & 400 & 466 & 525 \\
4 & Nesher & 90 & North & 43 & 564 & 496 & 349 \\
5 & Kiryat Bialik & 25 & North & 53 & 424 & 703 & 447 \\
6 & Kiryat Binyamin & 5 & North & 40 & 223 & 412 & 256 \\
7 & Kiryat Tivon & 201 & North & 47 & 413 & 416 & 300 \\
8 & Afula & 57 & North & 44 & 836 & 550 & 405 \\
\hline 9 & Ra'anana & 54 & Coast & 38 & 173 & 291 & 229 \\
10 & Antolonsky & 34 & Coast & 32 & 470 & 626 & 386 \\
11 & Ashdod & 25 & Coast & 36 & 303 & 750 & 332 \\
12 & Ironi D & 12 & Coast & 34 & 424 & 507 & 327 \\
13 & Tel Aviv Central Station & 29 & Coast & 41 & 716 & 803 & 451 \\
14 & Ashkelon & 25 & Coast & 61 & 182 & 537 & 119 \\
\hline 15 & Jerusalem Efrata & 749 & Mountain & 106 & 2285 & 434 & 403 \\
16 & Jerusalem Bar Ilan & 770 & Mountain & 107 & 3063 & 641 & 518 \\
\hline 17 & Gedera & 70 & South & 34 & 433 & 683 & 308 \\
18 & Nir Israel & 30 & South & 25 & 363 & 638 & 228 \\
19 & Kiryat Gvaram & 95 & South & 42 & 376 & 870 & 300 \\
20 & Sde Yoav & South & 45 & 323 & 245 & 228 \\
21 & Negev Mizrahi & South & 42 & 1748 & 526 & 317 \\
\hline
\end{tabular}

tion number 40172). With respect to Stull (1988), the MLH was defined by the RS profiles as the height where an inversion in the temperature was identified along with a significant drop in relative humidity, strong wind shear and an increase in the virtual temperature (Uzan et al., 2016; Uzan and Alpert, 2012; Levi et al., 2011).

\subsection{Particulate matter monitors $\left(\mathbf{P M}_{10}, \mathbf{P M}_{2.5}\right)$}

PM monitors are low-volume flow rate Thermo Fisher Scientific type FH 62 C14 (beta attenuation method) and type 1405 tapered element oscillating microbalance method (TEOM). Both instruments report PM concentration every $5 \mathrm{~min}$. The location of PM measurement sites is given in Table 5. In the beta attenuation method (U.S. Environmental protection Agency, 1999: https://www3.epa.gov/ttnamti1/files/ambient/ inorganic/overvw1.pdf), low-energy beta rays are focused on deposits on a filter tape and attenuated according to the approximate exponential function of particulate mass (i.e., Beer's law). These automated samples employ a continuous filter tape. The attenuation is measured through an unexposed portion of the filter tape. The tape is then exposed to the ambient sample flow where a deposit is accumulated. The beta attenuation is repeated, and the difference in attenuation between the blank filter and the deposit is a measure of the accumulated concentration. The weighing principle used in the TEOM method (https://tools.thermofisher.com/ content/sfs/manuals/EPM-TEOM1405-Manual.pdf) is based on a mass change detected by the sensor as a result of the measurement of a change in frequency. The tapered element at the heart of the mass detection system is a hollow tube, clamped on one end and free to oscillate at the other. If additional mass is added, the frequency of the oscillation decreases and a precision electronic counter measures the oscillation frequency with a $10 \mathrm{~s}$ sampling period. An electronic control circuit senses oscillation and adds sufficient energy to the system to overcome losses while an automatic gain control circuit maintains the oscillation at a constant amplitude.

\subsection{AERONET}

The AErosol RObotic NETwork (AERONET) is a multiband photometer with an automatic Sun-tracking radiometer for direct Sun measurements with a spectral range of $340-1640 \mathrm{~nm}$ wavelengths. The photometer measures the solar extinction in each wavelength to compute aerosol optical depth (Holben et al., 1998). In Israel, AERONET units of type CE318-N (https://aeronet.gsfc.nasa.gov) operate in Sde Boker and the Weizmann Institute (Fig. 3). Unfortunately, the unit in Weizmann did not operate between 6 and 8 September 2015 due to power failure. For this study, data acquisition was comprised of AOD (500 nm wavelength) and Ångström exponent (440-870 $\mathrm{nm}$ wavelengths) based on AERONET level 2.0 (cloud screened and quality assured for instrument calibration). 
Table 6. Hourly maximum concentration of $\mathrm{PM}_{10}$, collected from 31 monitoring sites, between 7 and 10 September 2015 . The values are ranked from low (dark green) to high (dark red) values.

\begin{tabular}{|c|c|c|c|c|c|c|c|}
\hline \multirow[b]{2}{*}{ No. } & \multirow[b]{2}{*}{ Site } & \multirow[b]{2}{*}{ Height (m a.s.l.) } & \multirow[b]{2}{*}{ Region } & \multicolumn{4}{|c|}{$\mathrm{PM}_{10}\left(\mu \mathrm{g} \mathrm{m}^{-3}\right)$} \\
\hline & & & & 7-Sep-15 & 8-Sep-15 & 9-Sep-15 & 10 -Sep-15 \\
\hline 1 & Galil Maaravi & 297 & North & 114 & 3130 & 1987 & 1562 \\
\hline 2 & Karmelia & 215 & North & 39 & 1120 & 1008 & 765 \\
\hline 3 & Newe Shaanan & 240 & North & 104 & 3459 & 2471 & 1518 \\
\hline 4 & Haifa Port & 0 & North & 78 & 1600 & 1965 & 1699 \\
\hline 5 & Nesher & 90 & North & 117 & 3265 & 2746 & 1270 \\
\hline 6 & Kiryat Haim & 0 & North & 82 & 1161 & 1625 & 1088 \\
\hline 7 & Afula & 57 & North & 97 & 3239 & 2322 & 1961 \\
\hline 8 & Um El Kotof & 0 & Coast & 99 & 2025 & 2028 & 1630 \\
\hline 9 & Orot Rabin & 0 & Coast & 58 & 1152 & 1455 & 999 \\
\hline 10 & Barta & 0 & Coast & 112 & 2540 & 2345 & 1612 \\
\hline 11 & Caesarea & 19 & Coast & 54 & 1067 & 2116 & 1272 \\
\hline 12 & Rehovot & 70 & Coast & 88 & 2236 & 3045 & 1257 \\
\hline 13 & Givatayim & 0 & Coast & 112 & 1909 & 4014 & 1484 \\
\hline 14 & Yad Avner & 77 & Coast & 61 & 1738 & 2902 & 1252 \\
\hline 15 & Ameil & 20 & Coast & 96 & 2027 & 3472 & 1321 \\
\hline 16 & Shikun Lamed & 17 & Coast & 51 & 1701 & 3244 & 1097 \\
\hline 17 & Tel Aviv Central Station & 29 & Coast & 87 & 1420 & 2176 & 998 \\
\hline 18 & Ashkelon & 29 & Coast & 117 & 953 & 1692 & 551 \\
\hline 19 & Ariel & 546 & Mountain & 128 & 2723 & 1481 & 1358 \\
\hline 20 & Jerusalem Efrata & 770 & Mountain & 273 & 7820 & 1630 & 1437 \\
\hline 21 & Jerusalem Bar Ilan & 749 & Mountain & 181 & 5588 & 1191 & 966 \\
\hline 22 & Jerusalem Safra & 797 & Mountain & 491 & 10280 & 2389 & 1780 \\
\hline 23 & Gush Ezion & 960 & Mountain & 310 & 6230 & 1679 & 1119 \\
\hline 24 & Erez & 80 & South & 44 & 1000 & 1000 & 718 \\
\hline 25 & Beit Shemesh & 350 & South & 115 & 2097 & 1943 & 1788 \\
\hline 26 & Carmy Yosef & 260 & South & 85 & 1047 & 784 & 594 \\
\hline 27 & Modi'in & 267 & South & 185 & 2701 & 2245 & 1980 \\
\hline 28 & Bat Hadar & 54 & South & 65 & 1342 & 2563 & 841 \\
\hline 29 & Nir Galim & 0 & South & 94 & 1479 & 2292 & 1027 \\
\hline 30 & Negev Mizrahi & 577 & South & 183 & 9031 & 2806 & 1730 \\
\hline 31 & Eilat & 0 & South & 275 & 1867 & 1592 & 1684 \\
\hline
\end{tabular}

\subsection{Global, direct and diffuse solar radiation measurements}

Global solar radiation is measured by a Kipp \& Zonen pyranometer type CMP-11 in 22 sites (Fig. 20) operated by the IMS. The pyranometer produces $10 \mathrm{~min}$ measurements of the integrated radiation flux $\left(\mathrm{W} \mathrm{m}^{-2}\right)$ between 300 and $3000 \mathrm{~nm}$ wavelengths. Diffuse and direct radiation are also measured in Beit Dagan (coastal region, $31 \mathrm{~m}$ a.s.l.) and Be'er Sheva (southern region, $71 \mathrm{~m}$ a.s.l.). For diffuse radiation measurements, a ring is mounted over a pyranometer to avoid direct solar radiation. Direct radiation is measured by a Suntracker pyrheliometer.

\subsection{Satellite imagery}

\subsubsection{SEVIRI (MSG satellite)}

MSG is a new series of European geostationary satellites operated by the European Organisation for the Exploitation of Meteorological Satellites (EUMETSAT). Aboard the MSG is a 12-channel Spinning Enhanced Visible and Infrared Imager (SEVIRI) (Roebeling et al., 2006). The combination of RGB channels (12-10.8 $\mu \mathrm{m}$, green: $10.8-8.7 \mu \mathrm{m}$ and blue: $10.8 \mu \mathrm{m}$, respectively) produces imagery of dust in pink or magenta, dry land in pale blue during daytime and pale green at nighttime. Thick high-level clouds in red-brown tones and thin high-level clouds appear nearly black (http: //oiswww.eumetsat.int/). Access to EUMETSAT imagery is provided online by https://www.eumetsat.int/website/home/ Images/RealTimeImages/index.html. Several studies compared AOD from MSG-SEVIRI and AERONET measurements (Romano et al., 2013; Bennouna et al., 2009; Jolivet et al., 2008) showed the uncertainty of MSG-SEVIRI AOD decreases as AOD rises. For continental aerosol type, errors do not exceed $10 \%$ in viewing zenith angles between 20 and $50^{\circ}$. The MSG-SEVIRI AOD uncertainty it is expected to be under $15 \%$ (Mei et al., 2012) and even higher as the atmospheric AOD increases above 1.5 (EUMETSAT Scientific Validation Report SEVIRI aerosol optical depth; 23 October 2017). The North African Sandstorm Survey (NASCube; 

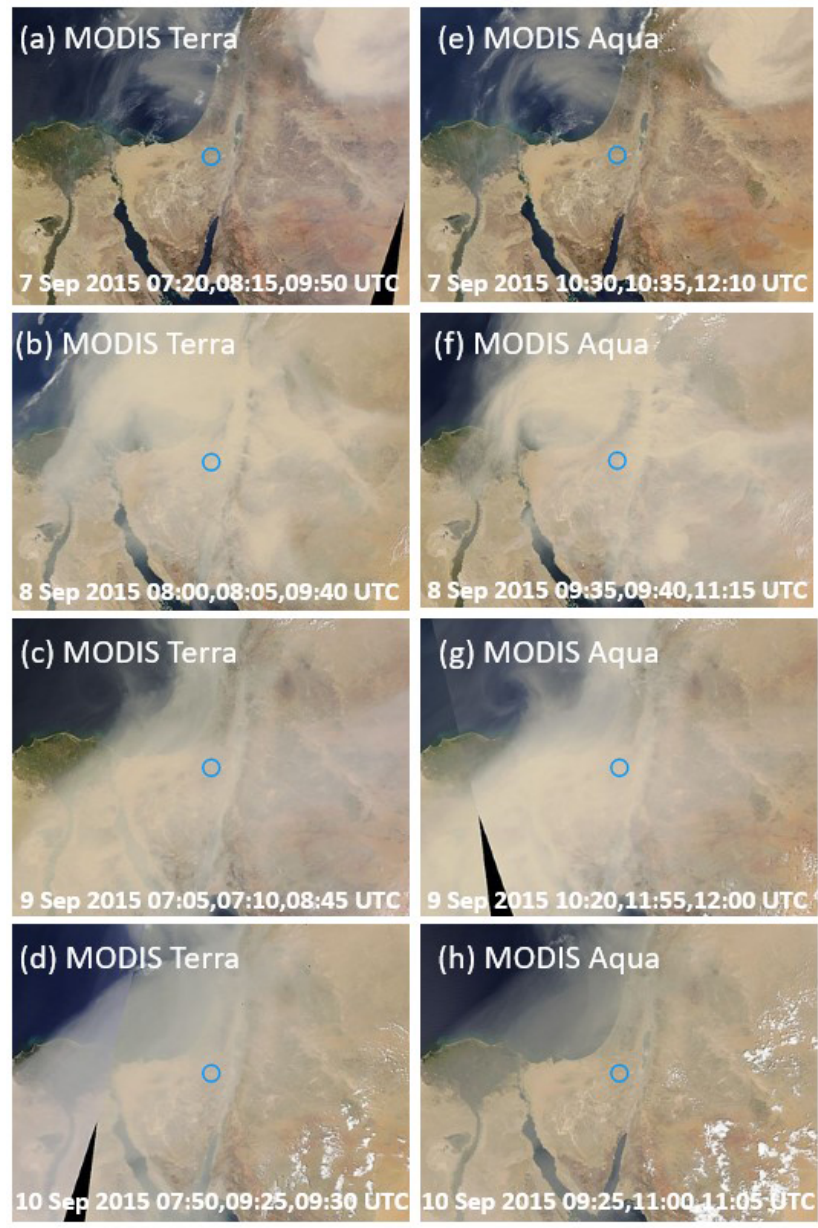

Figure 4. Pictures from MODIS Terra (a-d) and MODIS Aqua (eh). The date and time of overpass are indicated on each figure. The blue circle indicates the location of the AERONET Sde Boker site. Source: https://aeronet.gsfc.nasa.gov.

http://nascube.univ-lille1.fr) obtains AOD by temperature anomalies based on SEVIRI RGB by evaluating the difference in the emissivity of dust and desert surfaces during daytime.

\subsubsection{MODIS (Terra and Aqua satellites)}

The Moderate Resolution Imaging Spectroradiometer (MODIS) instrument is stationed aboard the Earth Observation System's (EOS) Terra and Aqua polar-orbiting satellites. Terra satellite is on a descending orbit (southward) over the Equator at $\sim 10: 30 \mathrm{LST}$. The Aqua satellite is on an ascending orbit (northward) over the Equator at $\sim 13: 30 \mathrm{LST}$. MODIS performs measurements by 36 channels between 412 and $14200 \mathrm{~nm}$, whereas the aerosol retrieval makes use of seven channels $(646,855,466,553,1243,1632$ and $2119 \mathrm{~nm}$ central wavelength) together with a number of other wavelength bands for screening procedures. Remer et al. (2006) revealed errors of 0.01 in the MODIS surface reflectance will lead to errors on the order of 0.1 in $\mathrm{AOD}$ retrieval. However, under conditions of high AOD (> 1.5), the uncertainty is expected to rise.

\subsubsection{CALIOP (CALIPSO satellite)}

CALIOP is a two-wavelength polarization lidar (1064 and $532 \mathrm{~nm}$ ) aboard CALIPSO that performs global profiling of aerosols and clouds in the troposphere and lower stratosphere (Winker et al., 2009). CALIOP measures signal returns in a large range from the aerosol-free region up to strong cloud returns. The CALIOP profiles are given below $40 \mathrm{~km}$ for the $532 \mathrm{~nm}$ channel and below $30 \mathrm{~km}$ for the $1064 \mathrm{~nm}$ channel. Data acquisition in this research was based on the level 2 version 4-10 CALIPSO product of $532 \mathrm{~nm}$ wavelength with a spatial resolution of $5 \mathrm{~km}\left(20-50^{\circ} \mathrm{N}, 20-50^{\circ} \mathrm{E}\right)$ and vertical resolution of $60 \mathrm{~m}$ (limited up to $6 \mathrm{~km}$ ).

\section{Results and discussion}

The following description of the dust event will proceed chronologically from 7 to 10 September and include main findings from the different measuring instruments (Sect. 2). The order of the instruments described follows the most interesting features revealed, not necessarily in the same order for each day. We provide 2-D ceilometer plots (height vs. time) presenting the extreme dust plume descent only from $\sim 1 \mathrm{~km}$ a.s.l. due to the ceilometer limitation to detect signals from higher levels (explained in Sect. 2.1). Unlike the high-resolution ceilometers, CALIPSO overpass above Israel was available only on 10 September 2015, revealing dust distribution in various levels up to $5 \mathrm{~km}$ a.s.l.

\subsection{September 2015}

On 7 September, images from MODIS Aqua (Fig. 4a) and MODIS Terra (Fig. 4e) taken between 07:20 and 12:10 UTC show that the dust plume progressed from northeast in a nearcircular motion over the Mediterranean Sea. The penetration of the dust plume to Israel was indicated at the AERONET Sde Boker site at $\sim$ 05:00 UTC by an increase in AOD along with a decrease in the Angström exponent (Fig. 5). The connection between decreasing Ångström exponent values and the dust plume was pointed out by Mamouri et al. (2016) which presented values of linear depolarization ratio between 0.25 and 0.32 on 7 and 10 September, indicating the dominance of mineral dust. In addition, an increase in the PM concentration started at $\sim 05$ UTC (not shown) reaching the highest hourly values of $107 \mu \mathrm{g} \mathrm{m}^{-3} \mathrm{PM}_{2.5}$ (Table 5) and $491 \mu \mathrm{g} \mathrm{m}^{-3} \mathrm{PM}_{10}$ (Table 6) only in the Jerusalem elevated sites ( $\sim 800 \mathrm{~m}$ a.s.l.) and only at 22:00 UTC. This $17 \mathrm{~h}$ gap is shown by the ceilometers' plots (Figs. 6-12) as a downward motion of the dust plume from $\sim$ 04:00 UTC in all measuring sites except for the elevated Mount Meron site (1150 m a.s.l., Fig. 13). Following the Gasch et al. (2017) cold-pool outflow 


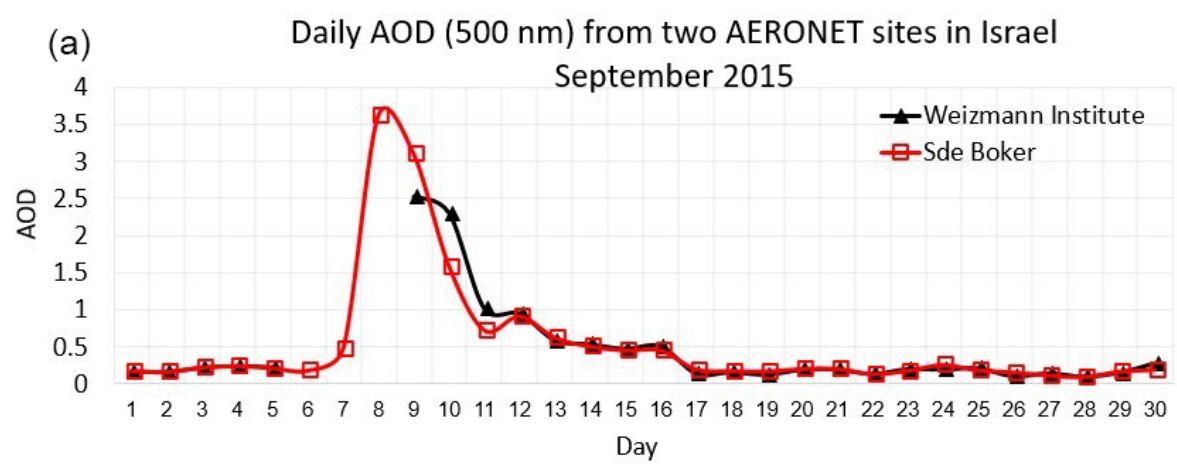

(b) Daily Angström exponent $(440-870 \mathrm{~nm})$ from two AERONET sites in

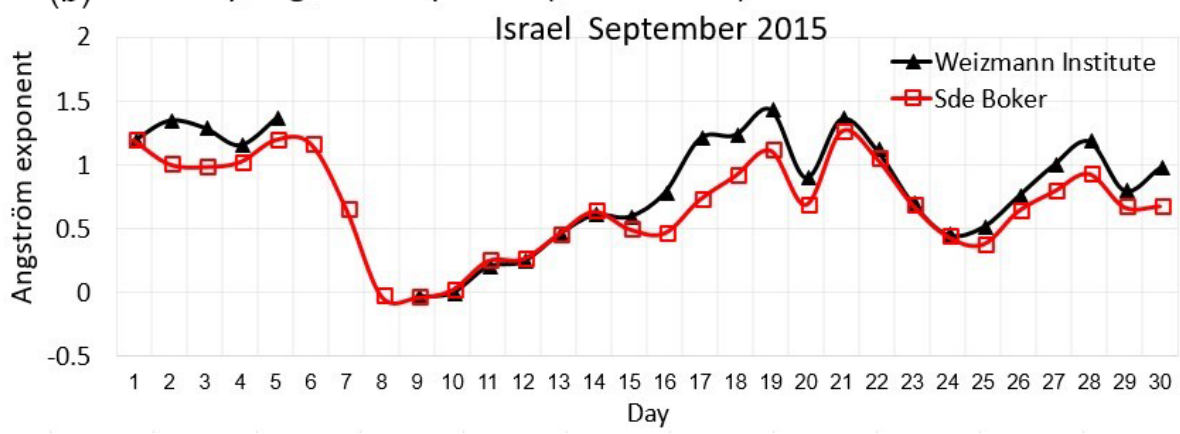

Figure 5. September 2015 daily average of AOD (a) and Ångström exponent (b) from two AERONET sites in Israel (Sde Boker and Weizmann; see Fig. 3). The Weizmann AERONET did not operate on 6-8 September due to power failure.

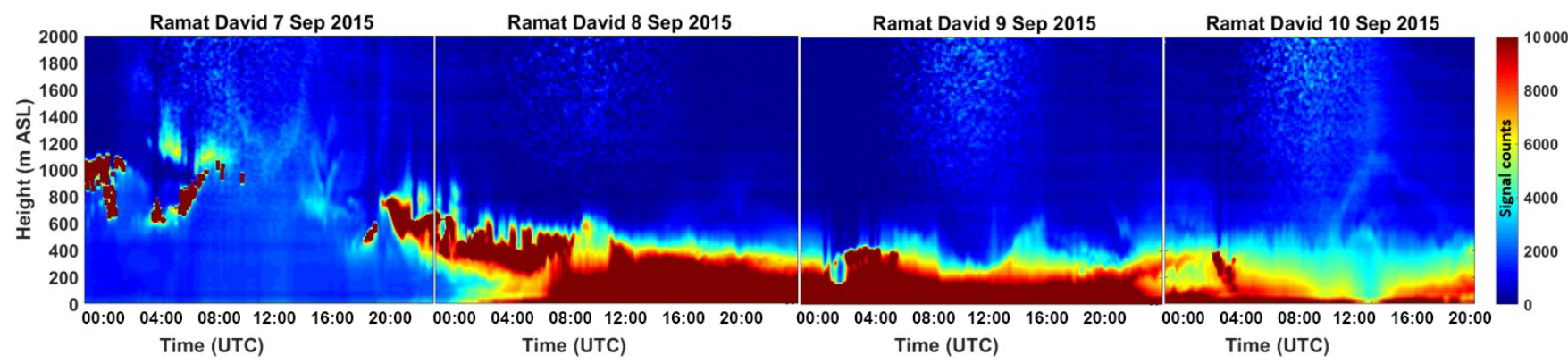

Figure 6. Ramat David ceilometer signal counts plots for 7-10 September 2015. The $y$ axis is the height up to $2000 \mathrm{~m}$ a.s.l., the $x$ axis is the time in UTC, and the signal count scale ranges between 0 and 10000 .

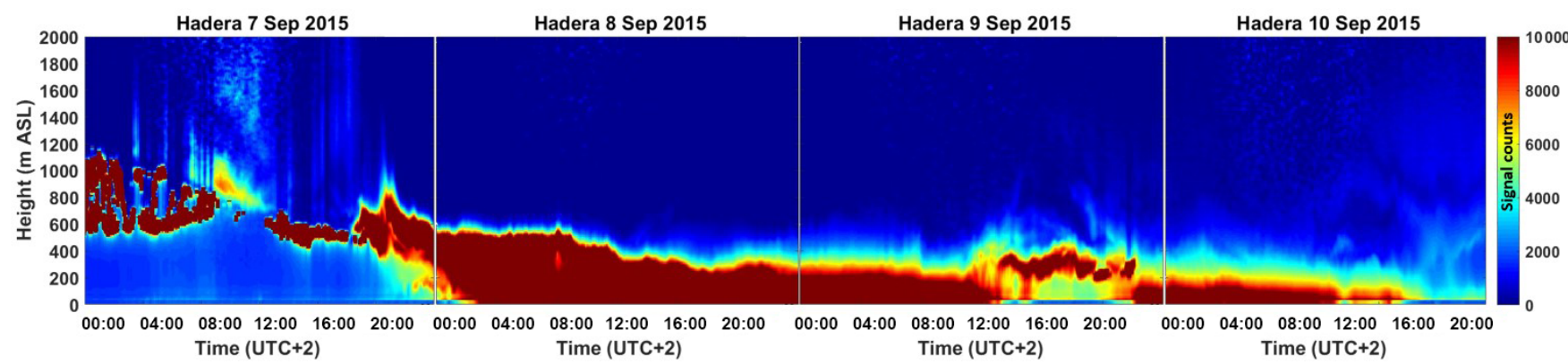

Figure 7. Hadera ceilometer signal counts plots for 7-10 September 2015. The $y$ axis is the height from site deployment to $2000 \mathrm{~m}$ a.s.1., the $x$ axis is the time in LST (UTC+2), and the signal count scale ranges between 0 and 10000 . 


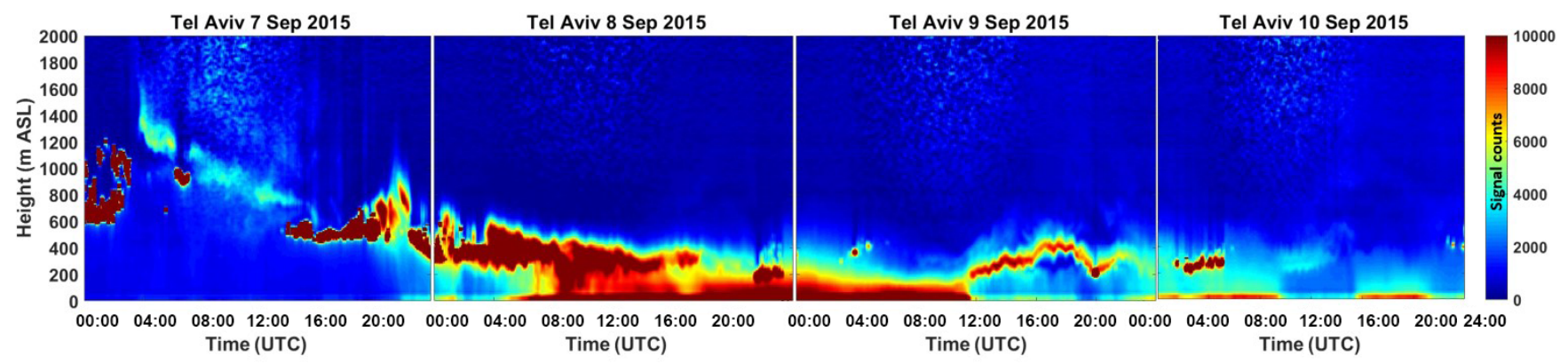

Figure 8. Tel Aviv ceilometer signal counts plots for 7-10 September 2015. The $y$ axis is the height from site deployment to 2000 m a.s.1., the $x$ axis is the time in UTC, and the signal count scale ranges between 0 and 10000 .

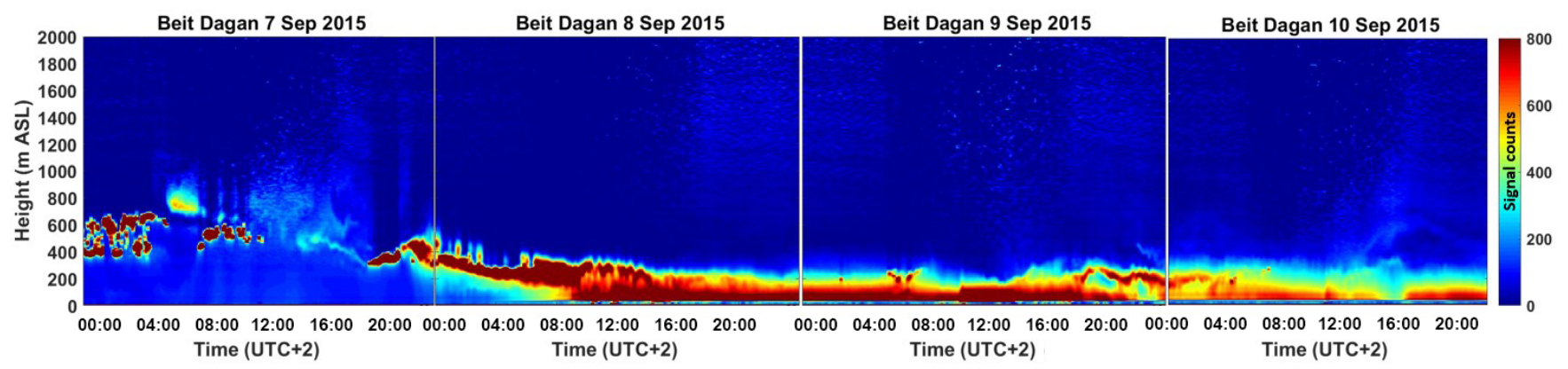

Figure 9. Beit Dagan ceilometer signal counts plots for 7-10 September 2015. The $y$ axis is the height from site deployment to 2000 $\mathrm{m}$ a.s.1., the $x$ axis is in LST (UTC+2), and the signal count scale ranges between 0 and 800 .

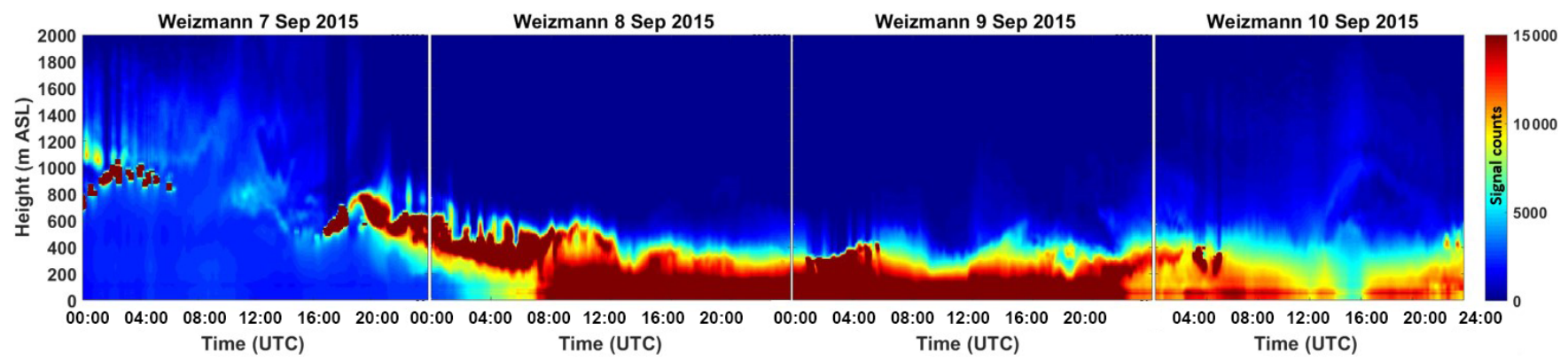

Figure 10. Weizmann ceilometer signal counts plots for 7-10 September 2015. The $y$ axis is the height from site deployment to 2000 $\mathrm{m}$ a.s.1., the $x$ axis is in UTC, and the signal count scale ranges between 0 and 15000 .

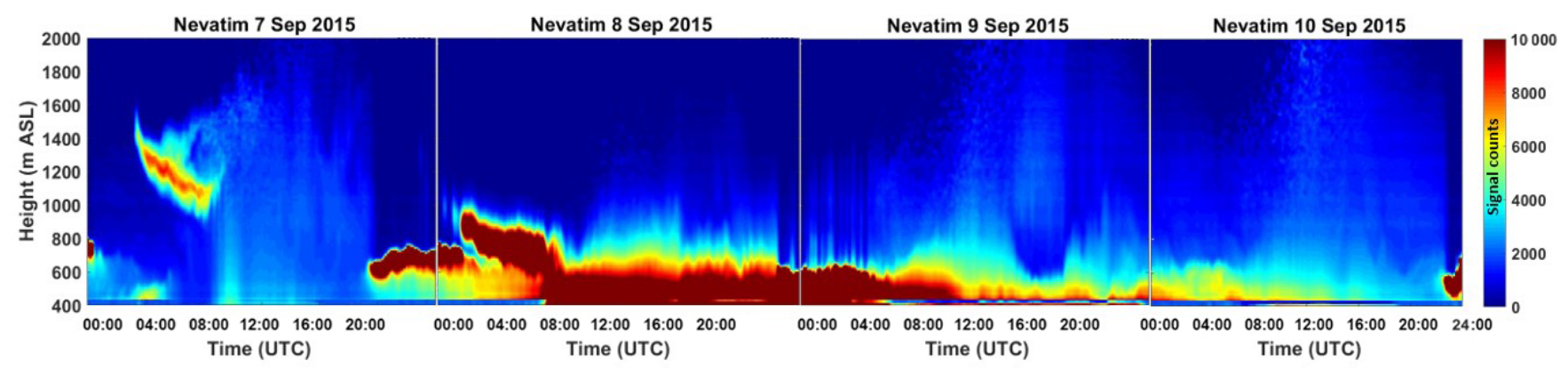

Figure 11. Nevatim ceilometer signal counts plots for 7-10 September 2015. The $y$ axis is the height from site deployment to $2000 \mathrm{~m}$ a.s.1., the $x$ axis is the time in UTC, and the signal count scale ranges between 0 and 10000 . 


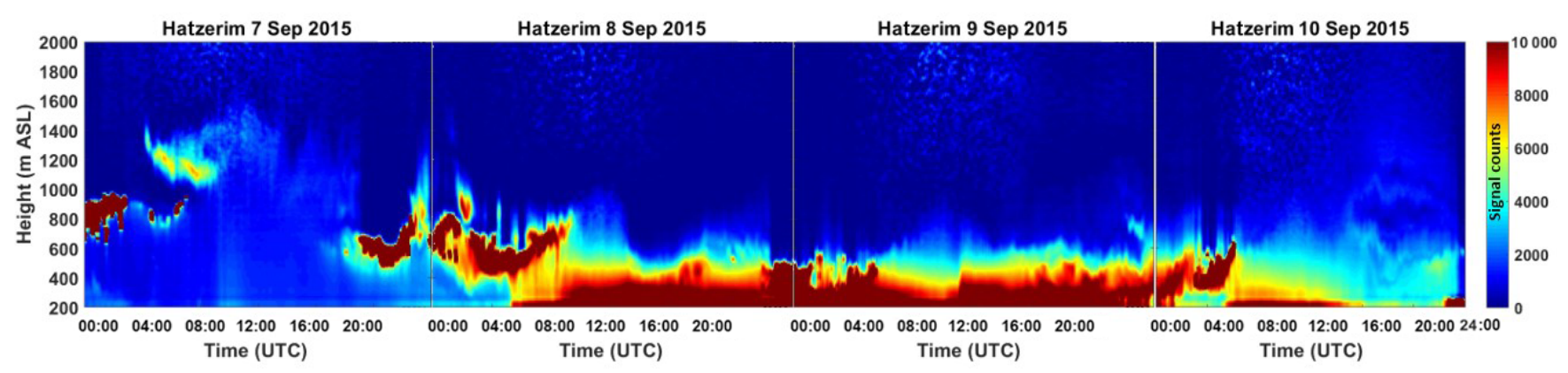

Figure 12. Hatzerim ceilometer signal counts plots for 7-10 September 2015. The $y$ axis is the height from site deployment to $2000 \mathrm{~m}$ a.s.1., the $x$ axis is the time in UTC, and the signal count scale ranges between 0 and 10000 .

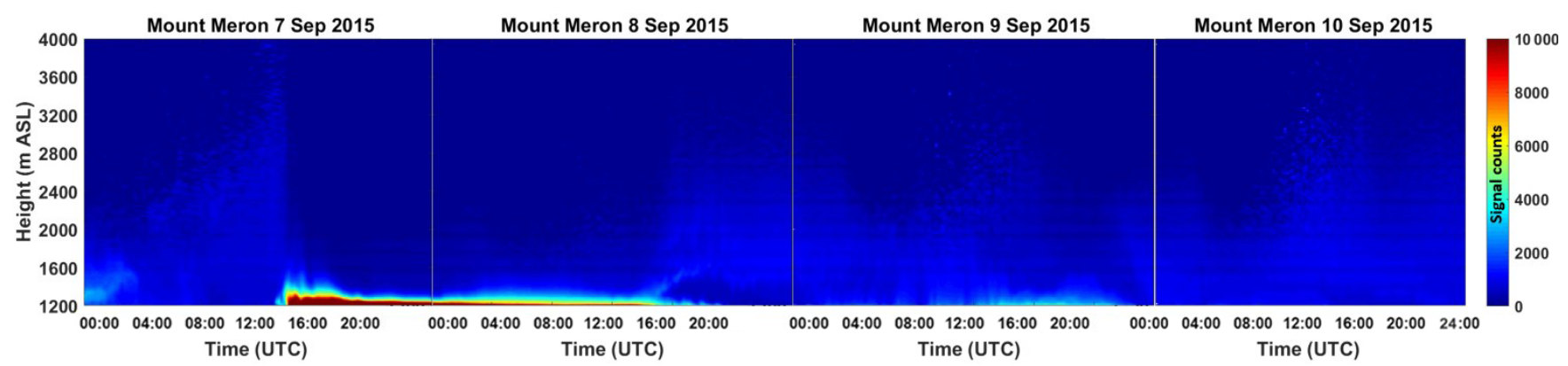

Figure 13. Mount Meron ceilometer signal counts plots for 7-10 September 2015. The $y$ axis is the height from site deployment to $4000 \mathrm{~m}$ a.s.l., the $x$ axis is the time in UTC, and the signal count scale ranges between 0 and 10000 .

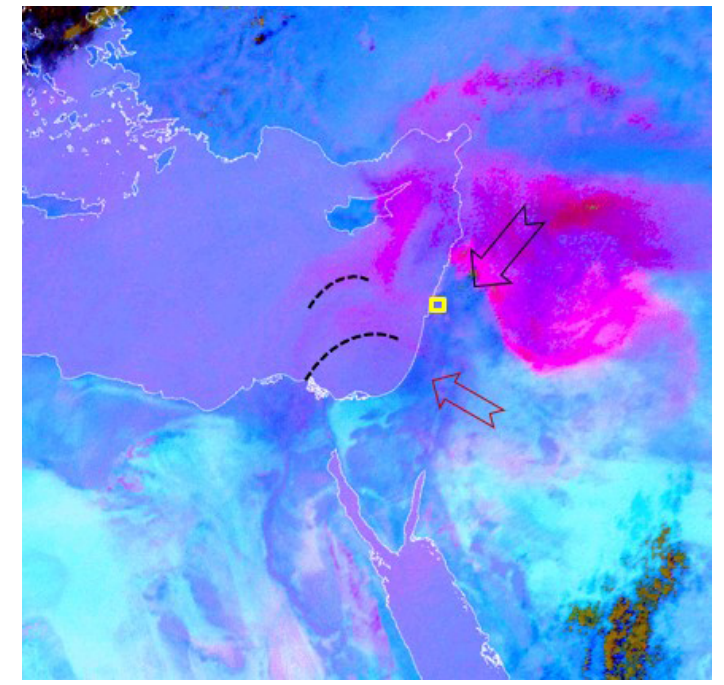

Figure 14. Picture from the MSG-SEVIRI satellite of the dust RGB component (dust appears in pink colors) on 7 September 2015 at 12:00 UTC with indications of the Mount Meron ceilometer site (yellow square: longitude $33.0^{\circ}$, latitude $35.4^{\circ}$ ) and the dust plumes' progression from east to west (red arrow and dashed lines) and from the northeast to southwest (black arrow).

concept, the exception of the Mount Meron site is supported by the MSG-SEVIRI picture (Fig. 14) showing that the first dust plume was fragmented (Fig. 14, red arrow) and the second dust plume (Fig. 14, black arrow) had not passed over Israel before 12:00 UTC. The deep blue scale evident in all Mount Meron ceilometer plots (Fig. 13) indicates total attenuation distinctively from 7 September at $\sim$ 14:00 UTC to 8 September at $\sim$ 16:00 UTC. However, due to the complexity of the dust plume progress (further shown) and the weak signal counts shown up to $3.5 \mathrm{~km}$ a.s.l. (before 7 September at $\sim 14: 00$ UTC and after 8 September at $\sim 16: 00$ UTC), the assumption of a total attenuation throughout the period analyzed is uncertain. Unfortunately, we did not have auxiliary measurements from the Mount Meron region to justify our assumptions.

While the MSG-SEVIRI picture at 12:00 UTC shows AOD values to be under 1 in most parts of Israel (Fig. 15), the PM concentrations at ground level were found to be bearable (up to $105 \mu \mathrm{g} \mathrm{m}^{-3} \mathrm{PM}_{2.5}$ and $305 \mu \mathrm{g} \mathrm{m}^{-3} \mathrm{PM}_{10}$, mainly in the Jerusalem elevated sites). At 12:00 UTC, Beit Dagan radiosonde profiles show a characteristic MLH of $700 \mathrm{~m}$ a.s.l. (Fig. 16). Moreover, at 23:00 UTC, the formation of clouds was indicated by ceilometers' profiles (Fig. 17a) at $400 \mathrm{~m}$ a.s.1. on the shoreline (Tel Aviv, $5 \mathrm{ma.s.1}$.) and up to $\sim 700 \mathrm{~m}$ a.s.l. in the elevated southern site (Nevatim, $400 \mathrm{~m}$ a.s.1.). Clouds are identified by the peak shape of the ceilometer profiles (Uzan et al., 2016) and the high rangecorrected signal of $10^{-1} \mathrm{~m}^{-1} \mathrm{sr}^{-1}$ which in this case was 4 orders of magnitude higher than the range-corrected signal of 

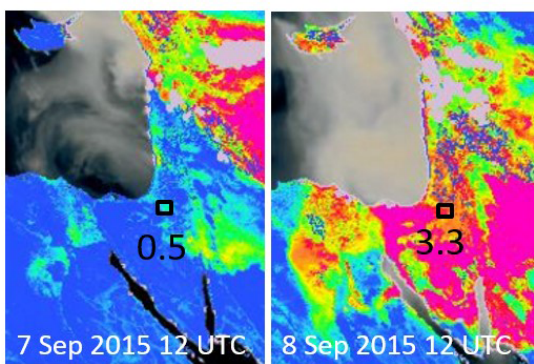
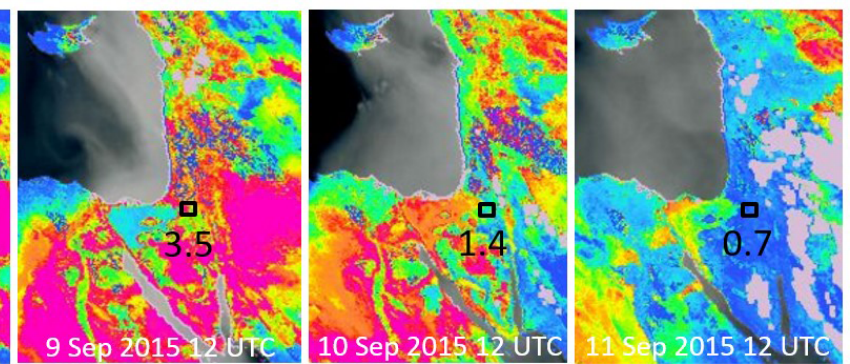

MSG-SEVIRI AOD

$\begin{array}{lllllllll}0.3 & 0.6 & 0.9 & 1.2 & 1.5 & 1.8 & 2.1 & 2.4 & 2.7\end{array}$

Figure 15. AOD at 12:00 UTC on 7-11 September 2015 analyzed by NASCube (Universite de Lille) based on imagery from the MSGSEVIRI satellite (by a combination of SEVIRI channels IR8.7, IR10.8 and IR12.0). The map includes indication of the Sde Boker AERONET site (black square) and its AOD value at 12:00 UTC.
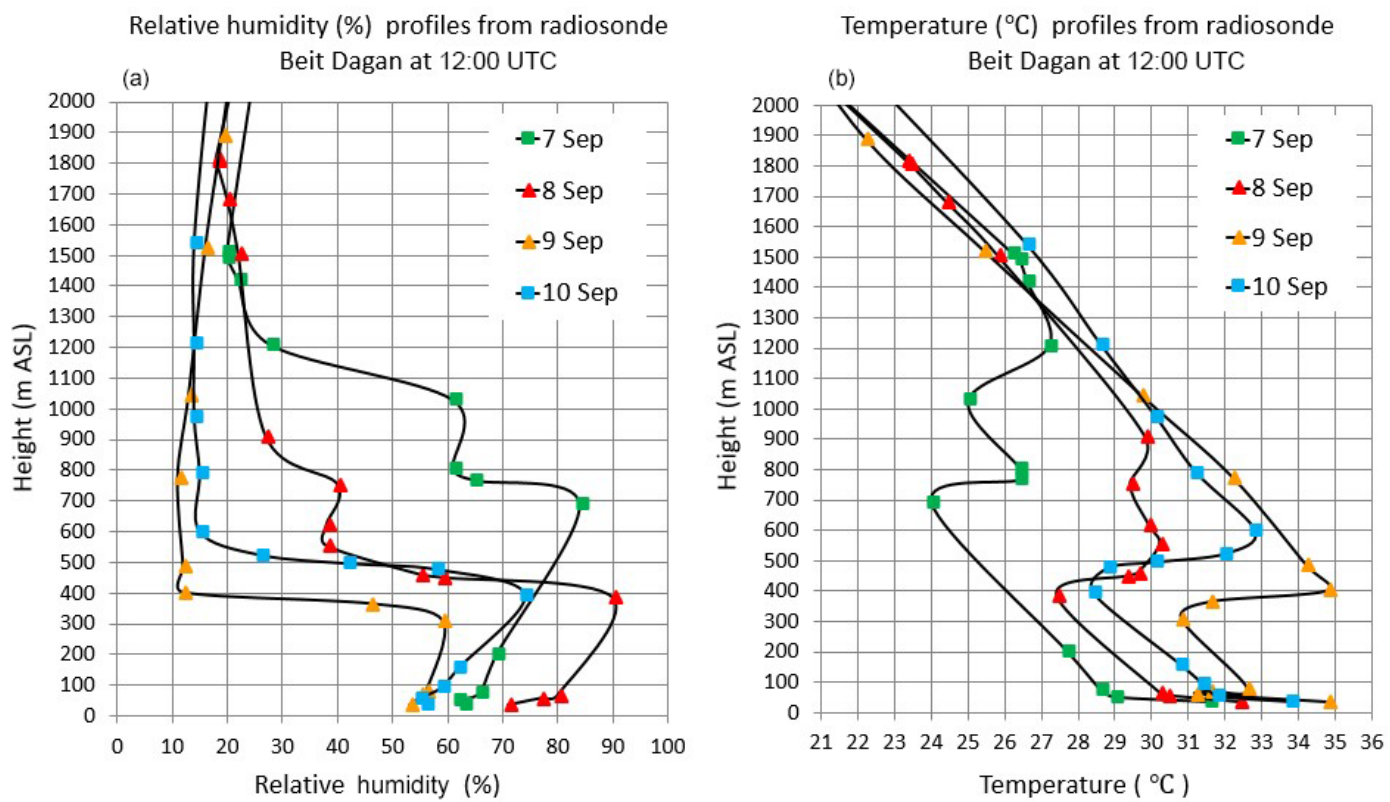

Figure 16. Radiosonde Beit Dagan profiles at 12:00 UTC between 7 and 10 September 2015 of relative humidity (a) and temperature (b).

the dust plume (shown in Fig. 17b-c). Hourly solar radiation measurements (Fig. 18; see 7 September daily plot) from Beit Dagan (central site) and Be'er Sheva (southern site) show a significant effect of the dust plume by a decrease in direct radiation along with an increase of diffuse radiation.

\subsection{September 2015}

The main phase (the peak) of the dust storm occurred on 8 September. Images from MODIS Aqua (Fig. 4b) and MODIS Terra (Fig. 4f) taken between 08:00 and 11:15 UTC show the dust storm prevailed over Israel. Ceilometers' plots detect the descending motion of the dust plume reached ground level at $\sim$ 08:00 UTC (Figs. 6-12). Simultaneously, Sde Boker AERONET AOD measurements increased up to $\sim 4$ along with a negative Ångström exponent (not shown).
An hour later, at 09:00 UTC, extreme maximum PM hourly values were measured in the elevated sites of Jerusalem's Safra Square (10280 $\left.\mu \mathrm{g} \mathrm{m}^{-3} \mathrm{PM}_{10}\right)$ and Bar Ilan $\left(3063 \mu \mathrm{g} \mathrm{m}^{-3} \mathrm{PM}_{2.5}\right)$, whereby on the coast and the lower northern regions, maximum PM values were measured only $14 \mathrm{~h}$ later at $\sim 23: 00 \mathrm{UTC}$ and were much lower (up to $3459 \mu \mathrm{g} \mathrm{m}^{-3} \mathrm{PM}_{10}$ and $470 \mu \mathrm{g} \mathrm{m}^{-3} \mathrm{PM}_{2.5}$; see Tables 5-6). Figure 19 illustrates the spatiotemporal variation of the $\mathrm{PM}_{10}$ extreme values, beginning at $\sim 12: 00$ UTC in the elevated Jerusalem sites and ending at midnight on the shoreline.

At $\sim$ 08:00 UTC, ceilometer plots from Tel Aviv, Beit Dagan, Weizmann and Hadera (with a higher scale range of 0-15 000; not shown here) reveal an non-uniform dust layer (beneath and above $\sim 300 \mathrm{~m}$ a.s.l.) that eventually combined into one dense layer. This process may explain the spatial 


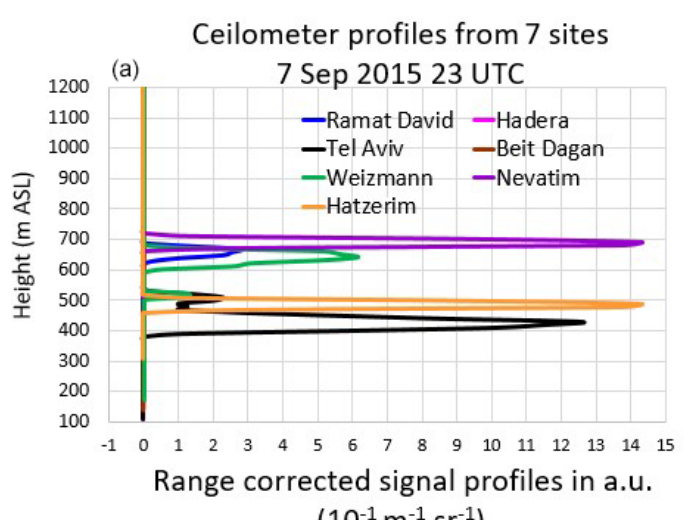

$\left(10^{-1} \mathrm{~m}^{-1} \mathrm{sr}^{-1}\right)$

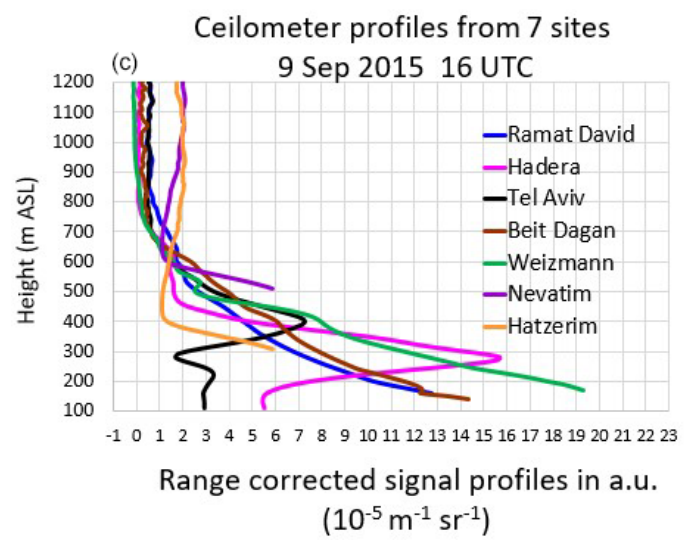

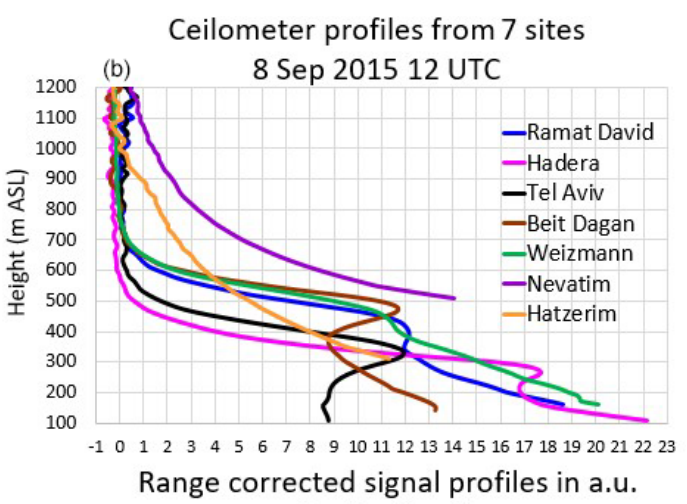

$\left(10^{-5} \mathrm{~m}^{-1} \mathrm{sr}^{-1}\right)$

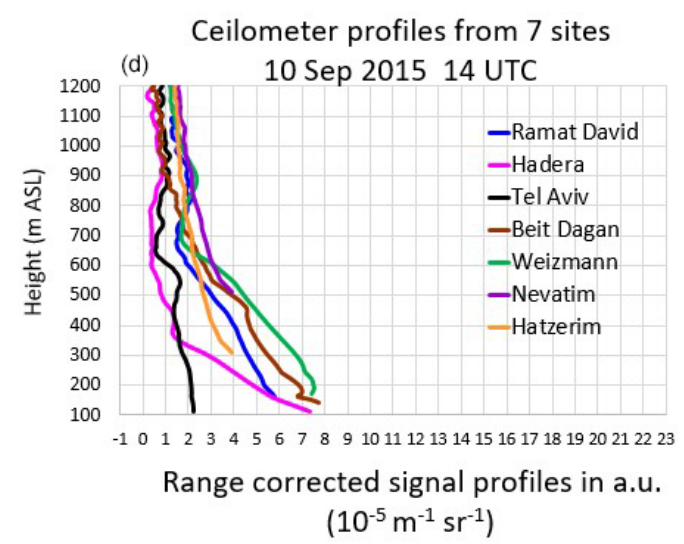

Figure 17. Ceilometer range-corrected signal profiles (in arbitrary units) from seven sites (Ramat David, Hadera, Tel Aviv, Beit Dagan, Weizmann, Nevatim and Hatzerim; see locations in Fig. 3) on 7 September 2015 at 23:00 UTC (a), 8 September 2015 at 12:00 UTC (b), 9 September 2015 at 16:00 UTC (c) and 10 September 2015 at 14:00 UTC (d). Notice that each profile begins relatively to the height of its measuring site (a.s.1.), including a deletion of data from the first $100 \mathrm{~m}$ a.g.l. due to inaccuracies in the first range gates of the ceilometers (for details, see Sect. 2.1). Panel (a) shows cloud detection; therefore, it is given in a different scale $\left(10^{-1} \mathrm{~m}^{-1} \mathrm{sr}^{-1}\right)$ and a different $x$-axis range.

variation and time delay between the extreme PM measurements in the elevated and lower sites.

MSG-SEVIRI at 12:00 UTC estimated AOD to be 2.7 while Sde Boker AERONET measured a higher value of 3.3 (Fig. 15). Furthermore, MODIS images (Fig. 4a, b) show a dominant dust plume over Israel, whereas solar global radiation measurements (Fig. 20a) present significant spatial variations, as minimum values (down to $200 \mathrm{~W} \mathrm{~m}^{-2}$ ) were measured mainly in northern Israel. Additionally, in spite the extreme $\mathrm{PM}_{10}$ values of $9031 \mu \mathrm{g} \mathrm{m}^{-3}$ measured in the elevated southern site (Negev Mizrahi: $577 \mathrm{~m}$ a.s.l.; Table 6), the maximum global radiation in southern Israel was still relatively high $\left(\sim 500 \mathrm{~W} \mathrm{~m}^{-2}\right)$. Generally, the radiative transfer analysis during heavy dust loads is complicated and relies on several parameters such as size, structure and composition of the aerosols (Bauer et al., 2011; Derimian et al., 2016). Dense dust layers such as in this extreme dust storm definitely had an impact on the radiation budget, hence changing weather patterns and air mass transport. The spatial variation of ground-level measurements compared to the quite uniform picture revealed by the satellites may infer the complexity of the dust plume evolution.

Overall, 8 September shows the highest PM concentrations and the lowest solar radiation levels for this dust storm event. The solar radiation was composed mainly of diffuse radiation (Fig. 18) emphasizing the immense atmospheric dust loads preventing direct insolation. Surprisingly, the low solar radiation was still able to warm the ground and generate a late and weak sea breeze front (not shown). We assume the insufficient ground heating generated weak thermals that could not inflate a MLH. Therefore, we assume the low MLH (300 m a.s.1.) revealed by radiosonde Beit Dagan profiles from 8 September (Fig. 16) may indicate the dust plume base height. As a result, the ceilometers' plots were fully attenuated above $\sim 300 \mathrm{~m}$ a.s.l.

\subsection{September 2015}

On 9 September, MODIS images (Fig. $4 \mathrm{c}$ and g) taken between 07:05 and 12:00 UTC show the dust plume progres- 

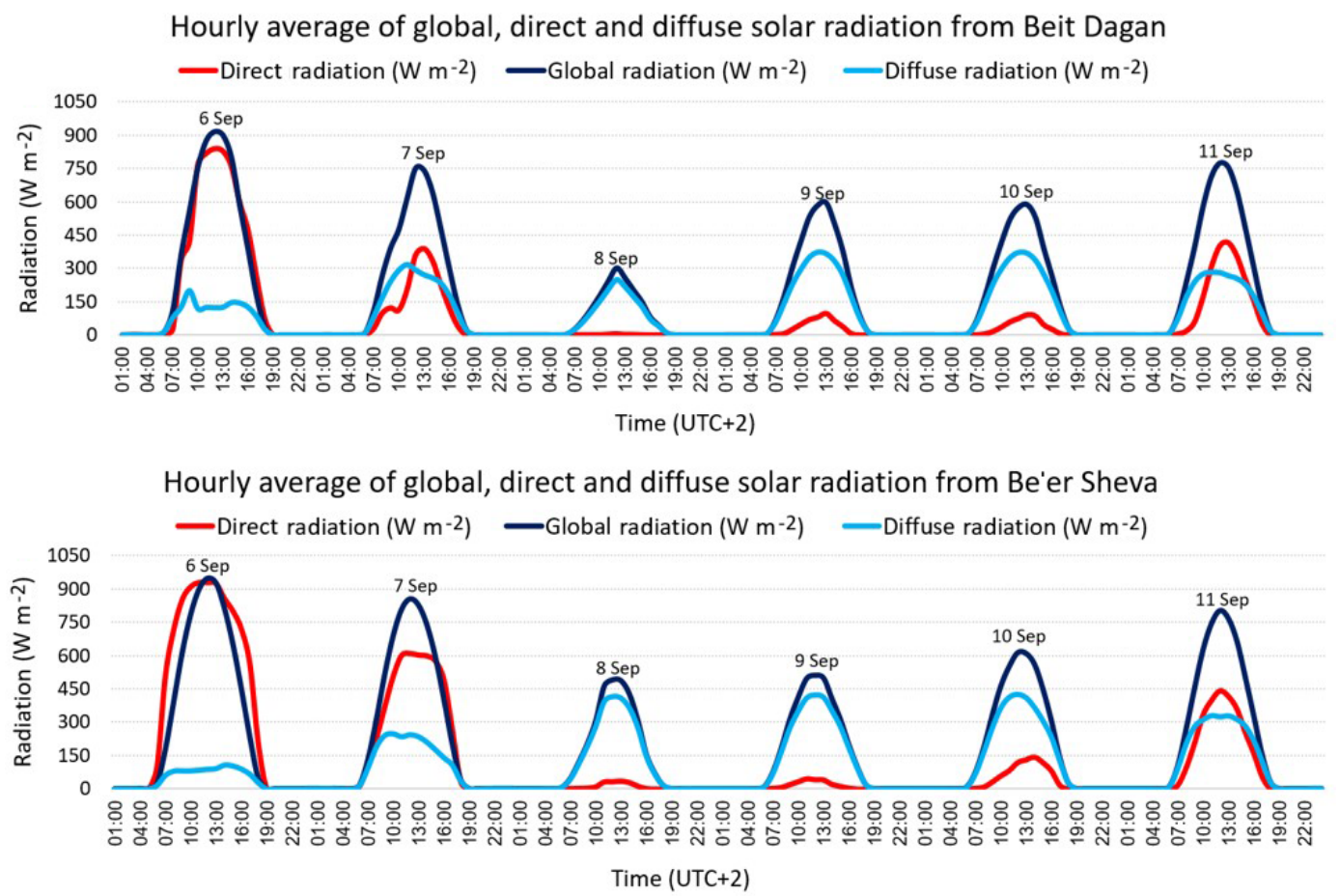

Figure 18. Hourly average of global, direct and diffuse solar radiation between 6 and 11 September 2015 from Beit Dagan and Be'er Sheva.

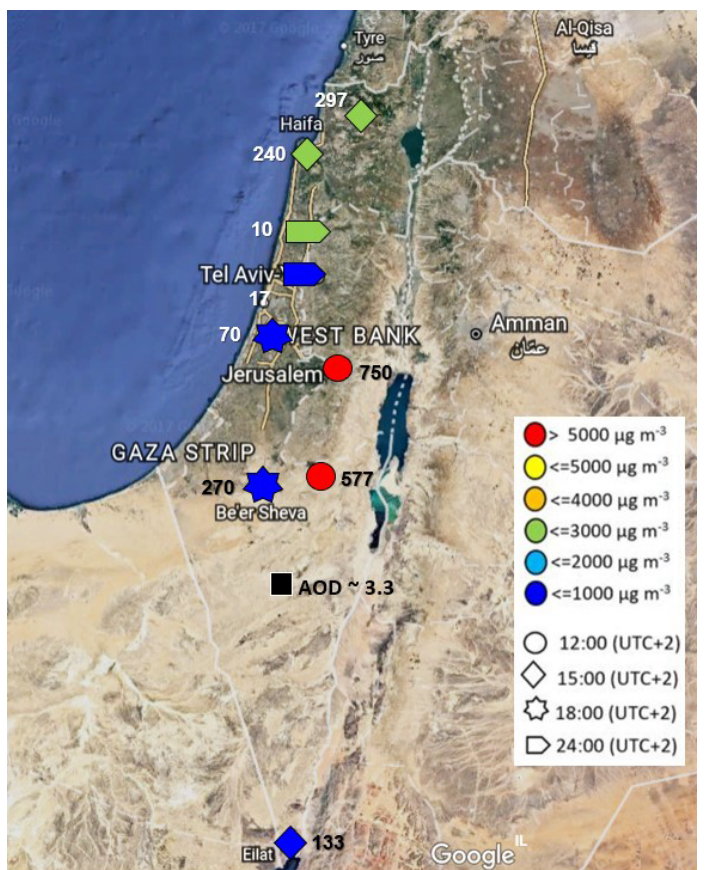

Figure 19. A map of $\mathrm{PM}_{10}$ maximum hourly concentrations from nine sites measured on 8 September 2015 at 10:00 UTC (midday). The map includes indications of the time of measurement (symbol shape), concentration range (symbol color), height of measurement site (numbers on map) and AOD from the AERONET Sde Boker site. sion southward to Egypt (Fig. 4), indicated by Sde Boker AERONET AOD $>3$ along with a negative Ångström exponent (Fig. 5). At 12:00 UTC, AOD from MSG-SEVIRI is 2.7, whereas Sde Boker AERONET AOD reached up to $\sim 3.5$ (Fig. 15). In contrast to the high AOD measurements, and the descent of the MLH down to $\sim 350 \mathrm{~m}$ a.s.l. (Fig. 16), PM values did not increase but rather decreased below $900 \mu \mathrm{g} \mathrm{m}^{-3} \mathrm{PM}_{2.5}$ (Table 5) and $4050 \mu \mathrm{g} \mathrm{m}^{-3} \mathrm{PM}_{10}$ (Table 6). The drop in PM concentration gave rise to an increase of solar radiation up to $400 \mathrm{~W} \mathrm{~m}^{-2}$ (Fig. 20b). An increase in solar radiation enables significant ground heating to values measured prior to the initiation of the dust storm (not shown), thus allowing generation of thermals and the creation of a late sea breeze cycle (Uzan et al., 2016). The entrance of the sea breeze front between 11:00 and 12:00 UTC eventually produced a narrow dust layer ascent visible in mainly on the coastline of Tel Aviv and Hadera ceilometers (Figs. 7-8). Interestingly, on 9 September, compared to the peak of the dust storm on the day before, we do not see a significant difference in solar radiation in southern Israel, which continued to be relatively high at $\sim 500 \mathrm{~W} \mathrm{~m}^{-2}$ (Fig. 20b).

\subsection{September 2015}

On 10 September, MODIS pictures from 07:50 to 11:05 UTC (Fig. 4d and h) show the dust plume over Israel transported southeast from Syria-Iraq to Sinai-Egypt. The CALIPSO single overpass of Israel at 11:00-11:10 UTC revealed a dust layer up to $5 \mathrm{~km}$ a.s.l. (Fig. 21). This corresponds with 

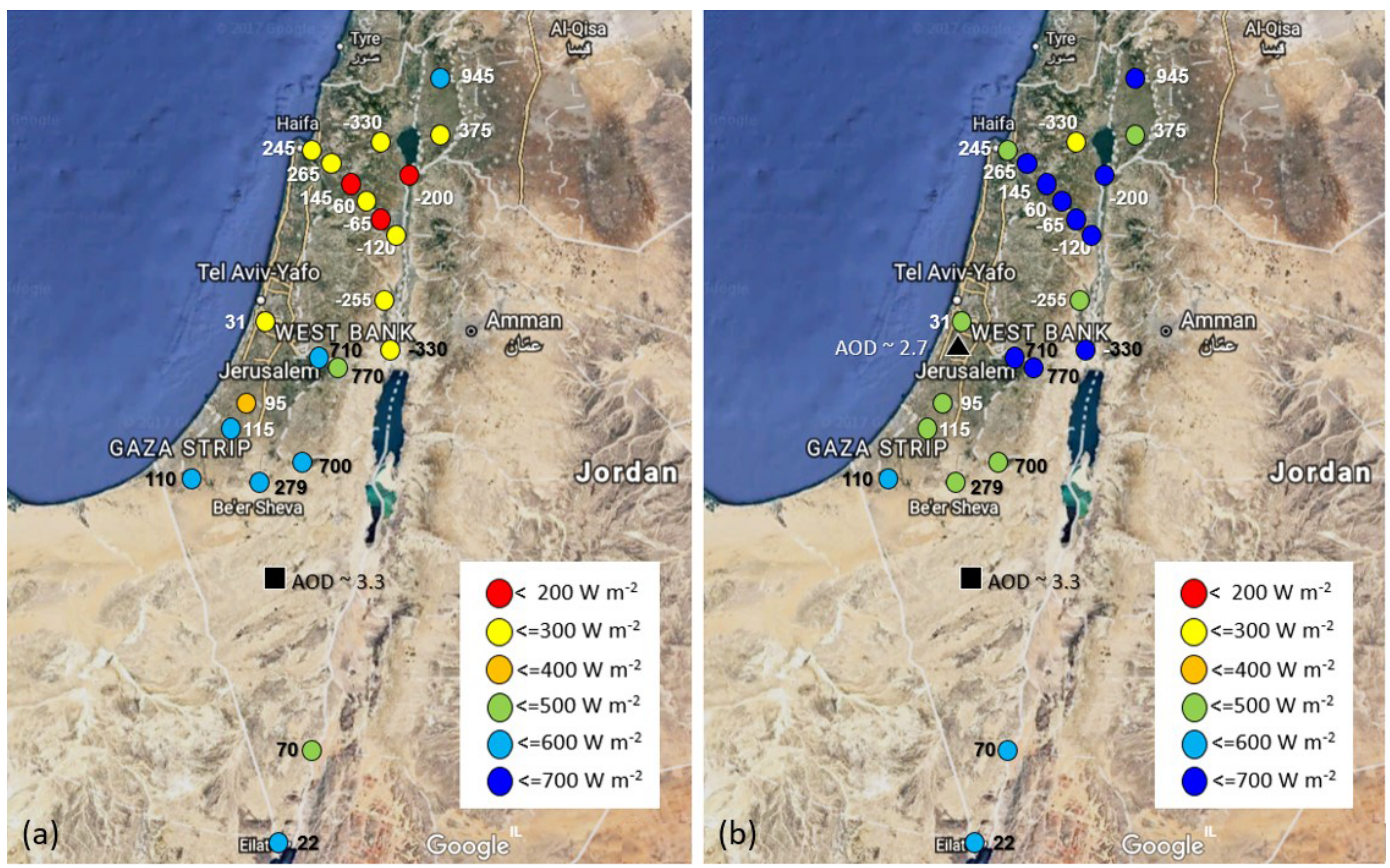

Figure 20. A map of maximum global solar radiation from 22 sites measured at 10:00 UTC (midday) on 8 September 2015 (a) and 9 September 2015 (b). The map includes indications of the radiation range (see legend), height of measurement site (numbers on the map) and AOD from the AERONET Sde Boker site (black square) and Weizmann site (black triangle). On 8 September, AERONET at the Weizmann site did not operate due to power failure.

the EARLINET lidar measurements in Limassol, Cyprus (Mamouri et al., 2016), detecting a dust plume between 1 and $3 \mathrm{~km}$ a.s.l. We assume the CALIOP lidar did not produce data beneath $2 \mathrm{~km}$ a.s.l. due to total attenuation. Fortunately, the ceilometers complement the dust profile (beneath $\sim 1 \mathrm{~km}$ a.s.l.), showing a reduction both in signal counts (Figs. 6-12) and in range-corrected signal profiles (Fig. 17d) pointing out a reduction in atmospheric dust loads. AODs from MSG-SEVIRI and Sde Boker AERONET show a decrease down to $\sim 1.5$ and a low Ångström exponent of $\sim 0.5$ indicating prevalence of mineral dust.

A profound reduction in PM values, down to a third of the values from the day before (Table 6), was evident mainly in southern Israel. Therefore, an increase in direct radiation was measured in southern site (Fig. 18). The reduction of dust loads may also be denoted by the orange background color of the photograph taken on 8 September (Fig. 1b) compared to the grey background visible on 10 September (Fig. 1c). As the dust storm dissipated, cloud formation (indicated by brown spots and evaluated by ceilometer profiles not shown) was visible from $\sim$ 04:00 UTC by ceilometers at Ramat David (Fig. 6), Tel Aviv (Fig. 8), Weizmann (Fig. 10) and Hatzerim (Fig. 11). The clouds' formation was not evident by MODIS imagery (Fig. 4d, h).

In the attempt to determine the "end" of the dust storm over Israel, we analyzed measurements from all instruments (Sect. 2) seeking values that were measured prior to the dust storm penetration. AERONET AOD values (Fig. 5), solar radiation measurements (not shown) and satellite imagery from MODIS and SEVIRI (not shown) indicate clearance of the dust storm on 17 September. On the other hand, PM values and ceilometer profiles indicated the dust storm ended 4 days earlier on 13 September (not shown). The difference between the measurements that include atmospheric layers aloft (satellite imagery, solar radiation and AERONET AOD) compared to measurements limited to the lower atmosphere (PM values and ceilometers) postulates a scheme of several dust layers or multiple sources of the dust plumes, which may support similar conclusions from previous studies (Solomos et al., 2017; Mamouri et al., 2016; Gasch et al., 2017).

\section{Conclusions}

A very severe dust storm struck the EM in September 2015. Previous investigations presented in situ and remote sensing measurements, discussed the initiation of the dust storm in the Syrian-Iraqi border, aspects of its transport over the EM and the limitations of the models to forecast this unique event. The analysis concentrated mainly on the upper level of the atmosphere at specific time segments of the dust storm. The benefit of this study is the provision of continuous measurements of vertical dust profiles in the lower part of the troposphere from eight ceilometer sites. The data presented here can be used as a tool to verify state-of-the-art model 

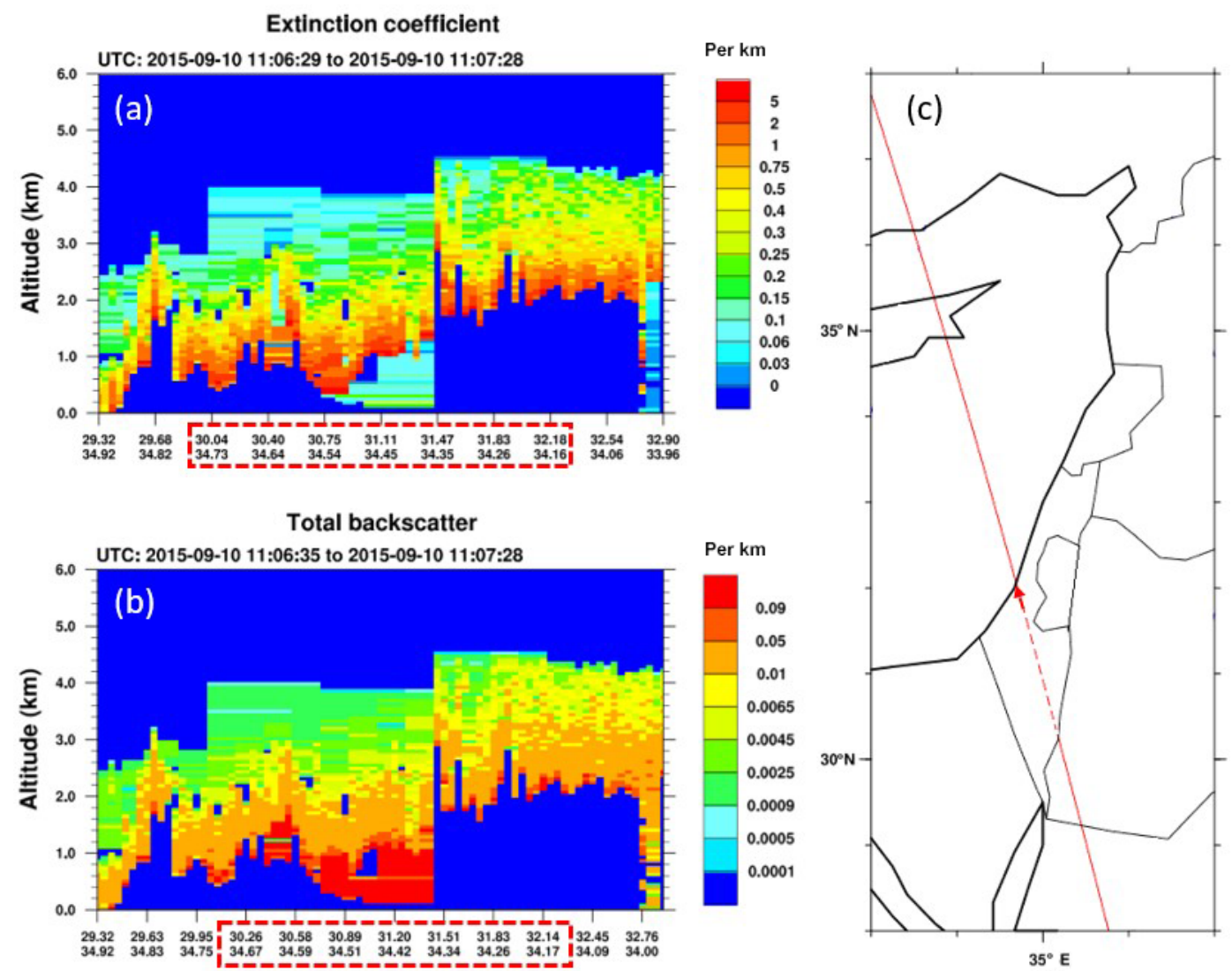

Figure 21. (c) A map of the EM centered on Israel with indication of CALIPSO satellite overpass from southeast to northwest (red line) on 10 September 2015 at 11:00-11:10 UTC. CALIOP lidar products (from $532 \mathrm{~nm}$ wavelength) of the extinction coefficient (a) and total backscatter (b) are given along the path over Israel (dashed red line). The ground elevation begins from $-20 \mathrm{~m}$ a.s.1. at the southeastern point. A quarter of the way through, the ground level rises up to $\sim 600 \mathrm{~m}$ a.s.l. and then gradually declines to sea level height as it reaches the shoreline in the northwestern point.

simulations and provide a different point of view to the meteorological conditions governing the dust plume advection over the EM.

This study confirmed that the dust storm entered Israel on 7 September and showed the gradual downfall of the dust plume from $\sim 1000 \mathrm{~m}$ a.s.l. on 7 September down to $\sim 400$ m a.s.l. on 8 September. The detailed ceilometer profiles and auxiliary instruments enabled to separate the dust storm into separated dust layers (beneath and above $1 \mathrm{~km}$ ). As the dust plume descended towards ground level on 8 September, PM concentration increased in the elevated stations (up to $10280 \mathrm{\mu g} \mathrm{m}^{-3}$ of $\mathrm{PM}_{10}$ ) and radiation decreased down to $\sim 200 \mathrm{~W} \mathrm{~m}^{-2}$ mainly in the northern region.

On 9 September, in spite of the high AOD (above 3), the global radiation (mainly comprised of diffuse radiation) increased, thus enabling sufficient ground heating for the creation of a late sea breeze front (between 11:00 and 12:00 UTC). The sea breeze circulation generated a narrow dust layer detached from the ground in the coastal region (Tel Aviv, Hadera and Beit Dagan).
On 10 September, the dust plume motion continued southwest to Egypt, indicated by CALIPSO as dust layers up to $5 \mathrm{~km}$. The end of the dust storm over Israel was indicated on 17 September by satellite imagery, solar radiation and AERONET AOD, while measurements limited to the lower atmosphere (PM values and ceilometers) indicated the dust storm ended on 13 September. The difference between the various instruments suggests a scheme of several dust layers or multiple sources of the dust plumes.

To conclude, ceilometers have been found to be a crucial tool in the study of the September dust storm evolution over Israel. In general, ceilometers provide a high-resolution database (temporal and spatial) that broadens the scope of the atmospheric measurements. Fortunately, as worldwide ceilometer deployment expands, ceilometers are realized as an essential tool in the analysis of meteorological phenomena and aerosol transport that is most valuable in the mesoscale.

Data availability. The Israeli Environmental Protection Ministry: $\mathrm{PM}_{10}$ and $\mathrm{PM}_{2.5}$ measurements, available at: 
http://www.sviva.gov.il/subjectsEnv/SvivaAir/AirQualityData/ NationalAirMonitoing/Pages/default.aspx, last access: December 2017 (in Hebrew).

The Israeli Meteorological Service: Solar radiation measurements, available at: http://www.ims.gov.il/, last access: December 2017 (in Hebrew).

Wyoming University: Radiosonde profiles, available at: http: //weather.uwyo.edu/upperair/sounding.html, last access: December 2017.

NASCube data center from the Université de Lille: The MSGSEVIRI imagery, available at: http://nascube.univ-lille1.fr/cgi-bin/ NAS3_v2.cgi, last access: December 2017.

EUMETSAT: MSG SEVIRI imagery, available at: https://www. eumetsat.int/website/home/Images/RealTimeImages/index.html, last access: June 2017.

NASA: MODIS imagery and AERONET measurements, available at: https://aeronet.gsfc.nasa.gov/, last access: December 2017.

Ceilometer profiles - the data are owned by governmental offices. The data are not online and are provided by request.

Author contributions. LU carried out the research and prepared the paper under the careful guidance of SE and PA.

Competing interests. The authors declare that they have no conflict of interest.

Acknowledgements. For the provision of ceilometer data, we wish to thank the Israeli Meteorological Service (IMS), the Israeli Air Force (IDF), association of towns for environmental protection (Sharon-Carmel) and Rafat Qubaj from the department of Earth and Planetary Science at the Weizmann Institute of Science. We give special thanks to Nir Stav (IMS) and Yoav Levy (IMS) for their fruitful advice, Anat Baharad (IMS) for computer assistance and Pavel Kunin (Tel Aviv University) for the CALIPSO images. We thank the principal investigators Arnon Karnieli and Yinon Rudich for their effort in establishing and maintaining the Sde Boker and Weizmann AERONET sites. We wish to thank the institutes that provide open-site data reduction: Université de Lille NASCube, Wyoming University Radiosonde and the Israeli Ministry of Environmental Protection for the PM data. Partial funding of this research was made by the Virtual Institute DESERVE (Dead Sea Research Venue).

Edited by: Hailong Wang

Reviewed by: two anonymous referees

\section{References}

Alpert, P., Osetinsky, I., Ziv, B., and Shafir, H.: A new seasons definition based on the classified daily synoptic systems: An example for the Eastern Mediterranean, Int. J. Climatol., 24, 1013-1021, 2004.

Ansmann, A., Bösenberg, J., Chaikovsky, A., Comerón, A., Eckhardt, S., Eixmann, R., Freudenthaler, V., Ginoux, P., Komguem, L., Linné, H., López Márquez, M. Á, Matthias, V., Mattis, I.,
Mitev, V., Müller, D., Music, S., Nickovic, S., Pelon, J., Sauvage, L., Sobolewsky, P., Srivastava, M. K., Stohl, A., Torres, O., Vaughan, G., Wandinger, U., and Wiegner, M.: Long-range transport of Saharan dust to northern Europe: The 11-16 October 2001 outbreak observed with EARLINET, J. Geophys. Res., 108, 4783-4798, https://doi.org/10.1029/2003JD003757, 2003.

Ansmann, A., Petzold, A., Kandler, K., Tegen, I. N. A., Wendisch, M., Mueller, D., Weinzierl, B., Mueller, T., and Heintzenberg, J.: Saharan Mineral Dust Experiments SAMUM-1 and SAMUM2: what have we learned?, Tellus B, 63, 403-429, 2011.

Bauer, S., Bierwirth, E., Esselborn, M., Petzold, A., Macke, A., Trautmann, T., and Wendisch, M.: Airborne spectral radiation measurements to derive solar radiative forcing of Saharan dust mixed with biomass burning smoke particles, Tellus B, 63, 742750, 2011.

Bennouna, Y. S., De Leeuw, G., Piazzola, J., and KusmierczykMichulec, J.: Aerosol remote sensing over the ocean using MSGSEVIRI visible images, J. Geophys. Res.-Atmos., 114, 114-132, 2009.

Derimian, Y., Karnieli, A., Kaufman, Y. J., Andreae, M. O., Andreae, T. W., Dubovik, O., Maenhaut, W., Koren, I., and Holben, B. N.: Dust and pollution aerosols over the Negev desert, Israel: Properties, transport, and radiative effect, J. Geophys. Res., 111, D05205, https://doi.org/10.1029/2005JD006549, 2006.

Donner, L. J., Wyman, B. L., Hemler, R. S., Horowitz, L. W., Ming, Y., Zhao, M., Golaz, J. C., Ginoux, P., Lin, S. J., Schwarzkopf, M. D., and Austin, J.: The dynamical core, physical parameterizations, and basic simulation characteristics of the atmospheric component AM3 of the GFDL global coupled model CM3, J. Climate, 24, 3484-3519, 2011.

EUMETSAT: MSG SEVIRI imagery, available at: https://www. eumetsat.int/website/home/Images/RealTimeImages/index.html, last access: June 2017.

Gasch, P., Rieger, D., Walter, C., Khain, P., Levi, Y., Knippertz, P., and Vogel, B.: Revealing the meteorological drivers of the September 2015 severe dust event in the Eastern Mediterranean, Atmos. Chem. Phys., 17, 13573-13604, https://doi.org/10.5194/acp-17-13573-2017, 2017.

Haeffelin, M. and Angelini, F.: Evaluation of Mixing - Height Retrievals from Automatic Profiling Lidars and Ceilometers in View of Future Integrated Networks in Europe, Bound.-Lay. Meteorol., 143, 49-75, 2012.

Holben, B. N., Eck, T. F., Slutsker, I., Tanre, D., Buis, J. P., Setzer, A., Vermote, E., Reagan, J. A., Kaufman, Y. J., Nakajima, T., and Lavenu, F.: AERONET - A federated instrument network and data archive for aerosol characterization, Remote Sens. Environ., 66, 1-16, 1998.

Hsu, N. C., Jeong, M.-J., Bettenhausen, C., Sayer, A. M., Hansell, R., Seftor, C. S., Huang, J., and Tsay, S.-C.: Enhanced Deep Blue aerosol retrieval algorithm: The second generation, J. Geophys. Res.-Atmos., 118, 9296-9315, https://doi.org/10.1002/jgrd.50712, 2013.

Jasim, F. H.: Investigation of the 6-9 September 2015 Dust Storm over Middle East, Am. J. Eng. Res., 5, 201-207, 2016.

Jolivet, D., Ramon, D., Bernard, E., Deschamps, P. Y., Riedi, J., Nicolas, J. M., and Hagolle, O.: Aerosol monitoring over land using MSG/SEVIRI. In Proceeding of the EUMETSAT Meteorological Satellite Conference, Darmstadt, Germany, 8-12, 2008. 
Kotthaus, S., O'Connor, E., Münkel, C., Charlton-Perez, C., Haeffelin, M., Gabey, A. M., and Grimmond, C. S. B.: Recommendations for processing atmospheric attenuated backscatter profiles from Vaisala CL31 ceilometers, Atmos. Meas. Tech., 9, 37693791, https://doi.org/10.5194/amt-9-3769-2016, 2016.

Levi, Y., Shilo, E., and Setter, I.: Climatology of a summer coastal boundary layer with $1290-\mathrm{MHz}$ wind profiler radar and a WRF simulation, J. Appl. Meteor., 50, 1815-1826, 2011.

Mamouri, R.-E., Ansmann, A., Nisantzi, A., Solomos, S., Kallos, G., and Hadjimitsis, D. G.: Extreme dust storm over the eastern Mediterranean in September 2015: satellite, lidar, and surface observations in the Cyprus region, Atmos. Chem. Phys., 16, 1371113724, https://doi.org/10.5194/acp-16-13711-2016, 2016.

Mei, L., Xue, Y., de Leeuw, G., Holzer-Popp, T., Guang, J., Li, Y., Yang, L., Xu, H., Xu, X., Li, C., Wang, Y., Wu, C., Hou, T., He, X., Liu, J., Dong, J., and Chen, Z.: Retrieval of aerosol optical depth over land based on a time series technique using MSG/SEVIRI data, Atmos. Chem. Phys., 12, 9167-9185, https://doi.org/10.5194/acp-12-9167-2012, 2012.

Mona, L., Liu, Z., Müller, D., Omar, A., Papayannis, A., Pappalardo, G., Sugimoto, N., and Vaughan, M.: Lidar measurements for desert dust characterization: an overview, Adv. Meteorol., 2012, 356265, https://doi.org/10.1155/2012/356265, 2012.

Münkel, C., Schäfer, K., and Emeis, S.: Adding confidence levels and error bars to mixing layer heights detected by ceilometer, Int. Proc. SPIE, 8177, 817708-1, 2011.

NASA: MODIS imagery and AERONET measurements, available at: https://aeronet.gsfc.nasa.gov/, last access: December 2017.

NASCube data center from the Université de Lille: The MSGSEVIRI imagery, available at: http://nascube.univ-lille1.fr/ cgi-bin/NAS3_v2.cgi, last access: December 2017.

Papayannis, A., Amiridis, V., Mona, L., Tsaknakis, G., Balis, D., Bösenberg, J., Chaikovski, A., De Tomasi, F., Grigorov, I., Mattis, I., and Mitev, V.: Systematic lidar observations of Saharan dust over Europe in the frame of EARLINET (2000-2002), J. Geophys. Res.-Atmos., 113, https://doi.org/10.1029/2007JD009028, 2008.

Parolari, A. J., Li, D., Bou-Zeid, E., Katul, G. G., and Assouline, S.: Climate, not conflict, explains extreme Middle East dust storm, Environ. Res. Lett., 11, 114013, https://doi.org/10.1088/1748-9326/11/11/114013, 2016.

$\mathrm{Pu}$, B. and Ginoux, P.: The impact of the Pacific Decadal Oscillation on springtime dust activity in Syria, Atmos. Chem. Phys., 16, 13431-13448, https://doi.org/10.5194/acp-16-134312016, 2016.

Rao, P. G., Hatwar, H. R., Al-Sulaiti, M. H., and Al-Mulla, A. H.: Summer shamals over the Arabian Gulf, Weather, 58, 471-478, 2003.

Remer, L. A., Tanre, D., Kaufman, Y. J., Levy, R., and Mattoo, S.: Algorithm for remote sensing of tropospheric aerosol from MODIS: Collection 005, National Aeronautics and Space Administration, available at: https://modis-atmos.gsfc.nasa.gov/ _docs/MOD04-MYD04_ATBD_C005.pdf, 1490, 2006.

Rieger, D., Bangert, M., Bischoff-Gauss, I., Förstner, J., Lundgren, K., Reinert, D., Schröter, J., Vogel, H., Zängl, G., Ruhnke, R., and Vogel, B.: ICON-ART 1.0 - a new online-coupled model system from the global to regional scale, Geosci. Model Dev., 8, 1659-1676, https://doi.org/10.5194/gmd-8-1659-2015, 2015.
Roebeling, R. A., Feijt, A. J., and Stammes, P.: Cloud property retrievals for climate monitoring: Implications of differences between Spinning Enhanced Visible and Infrared Imager (SEVIRI) on METEOSAT-8 and Advanced Very High Resolution Radiometer (AVHRR) on NOAA-17, J. Geophys. Res., 111, https://doi.org/10.1029/2005JD006990, 2006.

Romano, F., Ricciardelli, E., Cimini, D., Di Paola, F., and Viggiano, M.: Dust Detection and Optical Depth Retrieval Using MSGSEVIRI Data, Atmosphere, 4, 35-47, 2013.

Scientific Validation Report: SEVIRI Aerosol Optical Depth, EUMETSAT Satellite Application Facility on Climate Monitoring, https://doi.org/10.5676/EUM_SAF_CM/MSG_AOD/V001, 23 October 2017.

Solomos, S., Ansmann, A., Mamouri, R.-E., Binietoglou, I., Patlakas, P., Marinou, E., and Amiridis, V.: Remote sensing and modelling analysis of the extreme dust storm hitting the Middle East and eastern Mediterranean in September 2015, Atmos. Chem. Phys., 17, 4063-4079, https://doi.org/10.5194/acp17-4063-2017, 2017.

Stull, R. B.: An introduction to boundary layer meteorology, Kluwer Academic publishers, the Netherlands, 666 p., 1988.

The Israeli Environmental Protection Ministry: $\mathrm{PM}_{10}$ and $\mathrm{PM}_{2.5}$ measurements, available at: http://www.sviva.gov.il/subjectsEnv/ SvivaAir/AirQualityData/NationalAirMonitoing/Pages/default. aspx, last access: December 2017 (in Hebrew).

The Israeli Meteorological Service: Solar radiation measurements, available at: http://www.ims.gov.il/, last access: December 2017 (in Hebrew).

U.S. Environmental Protection Agency: Continuous measurement of $\mathrm{PM}_{10}$ suspended particulate matter (SPM) in ambient air, Center for Environmental Research Information Office of Research and Development, U.S. Environmental Protection Agency, Cincinnati, OH 45268, June 1999.

Uzan, L. and Alpert, P.: The coastal boundary layer and air pollution- A high temporal resolution analysis in the East Mediterranean Coast, The Open Atmospheric Science Journal, 6, 9-18, 2012.

Uzan, L., Egert, S., and Alpert, P.: Ceilometer evaluation of the eastern Mediterranean summer boundary layer height - first study of two Israeli sites, Atmos. Meas. Tech., 9, 4387-4398, https://doi.org/10.5194/amt-9-4387-2016, 2016.

Wang, Y. Q.: MeteoInfo: GIS software for meteorological data visualization and analysis, Met. Apps, 21, 360-368, 2014.

Wiegner, M. and Gasteiger, J.: Correction of water vapor absorption for aerosol remote sensing with ceilometers, Atmos. Meas. Tech., 8, 3971-3984, https://doi.org/10.5194/amt-8-3971-2015, 2015.

Wiegner, M., Madonna, F., Binietoglou, I., Forkel, R., Gasteiger, J., Geiß, A., Pappalardo, G., Schäfer, K., and Thomas, W.: What is the benefit of ceilometers for aerosol remote sensing? An answer from EARLINET, Atmos. Meas. Tech., 7, 1979-1997, https://doi.org/10.5194/amt-7-1979-2014, 2014.

Winker, D. M., Vaughan, M. A., Omar, A., Hu, Y., Powell, K. A., Liu, Z., Hunt, W. H., and Young, S. A.: Overview of the CALIPSO mission and CALIOP data processing algorithms, J. Atmos. Ocean. Tech., 26, 2310-2323, 2009.

Wyoming University: Radiosonde profiles, available at: http:// weather.uwyo.edu/upperair/sounding.html, last access: December 2017 . 